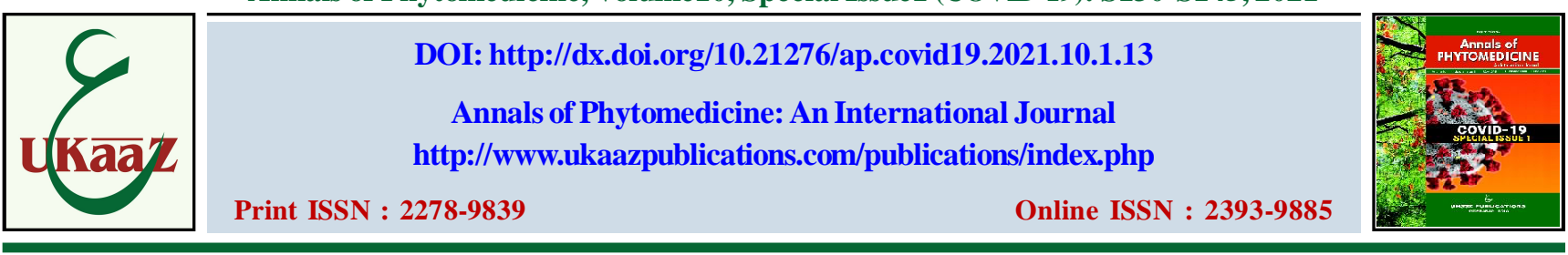

\title{
Edible dry fruits and seeds in combating second wave of COVID-19 pandemic
}

\author{
Sravani Singirikonda , M. Saifulla Khan, Kuntal Das, R. Tejashwini and A. Jothi \\ Krupanidhi College of Pharmacy, Department of Pharmacognosy and Phytochemistry, Carmelaram Post, Varthur Hobli, Chikkabellandur, \\ Bangalore-560035, Karnataka, India
}

\section{Article Info}

\section{Article history}

Received 4 April 2021

Revised 25 May 2021

Accepted 26 May 2021

Published Online 30 June 2021

Keywords
Antiviral
COVID-19
Dry fruits
Immunity
Phytochemicals
Seeds

\begin{abstract}
Dry fruits and few edible seeds are very common consumableitems with the rich source of polyphenolic compounds. Many other phytochemicals are also present in dry fruits and shows significant antioxidant activity that further correlated to get rid of many health complications. These fruits are commonly known as dry fruits or super foods with the rich content of proteins, vitamins, minerals and dietary fibre. They are well known for their immuno modulatory activities with various medicinal applications, especially as antiviral activity. The ongoing COVID outbreak has posed a serious threat to global health sector. At present, the second wave of coronavirus is already has started and gradually increasing day by day in worldwide which arestronger and much more detrimental for the people including in India. In connection with the previous history, it is obvious to increase immunity to fight against the pandemic virus. In the present manuscript, some important dry fruits and seeds are selected which have dual characters, i.e., potent immune boosting property along with antiviral efficacy. Various phytochemicals like flavonoids, alkaloids, glycosides, sesquiterpenes, benzoic compounds were reportedly isolated from these plant extracts those are having strong antiviral as well as immune boosting properties. Therefore, the detail study of these dry fruits and seeds with their sources, chemicals responsible for the therapeutic efficacy, their structural nature, and potent uses along with their combined preparations as home as remedies in boosting immunity and also to resist the viral infection are discussed. The article will focus to the researchers for detailed ethnopharmacological and phytochemical studies on these dry fruit and seed plants used to treat as immuno modulators as well as in the development of novel antiviral drugs.
\end{abstract}

\section{Introduction}

People are assaulted by severe epidemics of infectious disease from the time immemorial and have exacted a terrible toll. Some have changed the course of history too. Of late, COVID-19 outbreak is such a terrible situation throughout the world, caused by a detrimental virus, severe acute respiratory syndrome coronavirus 2 (SARS-CoV-2). Around the world, the sudden explosion of the COVID-19 pandemic has taken everybody at all levels astern in an unprecedented manner. The COVID-19 virus taints humans and animals both and is so deadly that produces severe pneumonia followed by respiratory collapse and finally death.The virus when started to spread first from China (Wuhan city) in December 2019, the researchers and scientists from over the globe are started to know the structural behavior and pathogenesis of the virus and came to know the similarities with the severe diseases like Middle East respiratory syndrome and severe acute respiratory syndrome (SARS) (Wu and McGoogan, 2020). The virus produces the similar symptoms as SARS and named as SARS-CoV-2 in January, 2020 by the Chinese Authority. Furthermore, they also revealed that the novel corona virus is zoonotic type that started to spread from animals (bats or pangolins) (Gao et al., 2020). Even it was also

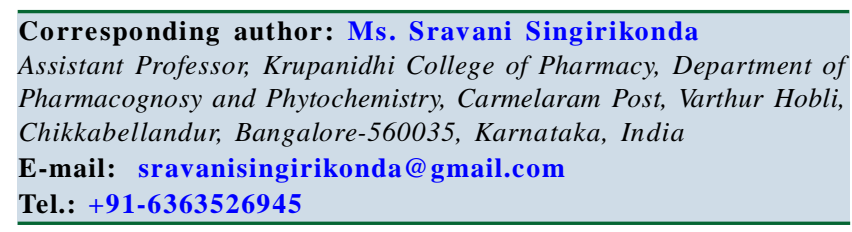

Copyright (c) 2021 Ukaaz Publications. All rights reserved.

Email: ukaaz@yahoo.com; Website: www.ukaazpublications.com revealed that the virus is faster spreading to the less immune peoples especially to the elderly people and the people with comorbidity, i.e., with multiple medical diseases. Finally, WHO has declared the COVID-19 as a pandemic on $11^{\text {th }}$ March, 2020 (WHO, 2020). The viruses named corona because of its crown like shape that contained single stranded, enveloped RNA covered with glycoprotein spikes on the surface (Khan et al., 2020). It is a group of beta coronavirus containing identical genome sequence $(79 \%)$ with SARS-CoV and with MERS-CoV (50\%) (Lu et al., 2020). A receptor binding site is present in the spike protein that recognizes the human angiotensinconverting enzyme 2 (ACE2) as its receptor (Li et al., 2005). With the help of the spike proteins on the envelope, binds to their cellular receptors that lead to the fusion between host cells and viral membranes for host cell entry by triggered the process with the help of multiple genes such as cytoplasmic domain (CP), fusion protein (FP), heptad repeats (HP), receptor binding site (RBD), receptor binding motif (RBM), signal peptide (SP), HR1-2 (heptad repeats 1-2), and the transmembrane protein (TM) (Xu et al., 2019) (Figure 1).

The virus rapidly spreads into the humans and further infected human spread infection to other human through various modes such as contact, surface infection, aerosolization of the virus particle during sneezing, coughing, etc. (Weijun et al., 2005; van Doremalen et al., 2020). The symptoms are like fever, dry cough and fatigue and in severer cases dyspnea. Particularly in children and young adults, the result is asymptomatic but older people and also people with comorbidities are at higher risk of severe disease, respiratory 
failure and death (Tian et al., 2020). The viral infected persons are confirmed with 2 types of assays such as immunologic assays to identify antibodies (by the double-antigen sandwich method with a recombinant $\mathrm{N}$ protein and a partial $\mathrm{S}$ protein of SARS-CoV, and results were confirmed by Western blot method) (Towbin et al., 1979) and reverse transcription polymerase chain reaction (RTPCR) to detect the viral genome which is carried out with virusspecific primers, extracted from blood samples and the total RNA was then reverse transcribed with random hexamers, and cDNA was amplified with a nested PCR method (Chen et al., 2004). Even though, the death toll of more than 27 Lakhs $(2.73 \mathrm{M})$ throughout the world as on $23^{\text {rd }}$ March, 2021, affected with 215 countries and territories worldwide. Among that, 1.60 lakhs death occurs in India only till $23^{\text {rd }}$ March, 2021. Due to global emergency at the earliest basis, numbers of vaccines arecome into the market. Among them, Covishield (ChAdOx1 nCoV-19 coronavirus vaccine, Recombinant), manufactured by Serum Institute of India Pvt. Ltd., with collaboration of the Oxford-AstraZeneca, Covaxin (an inactivated vaccine, developed by Bharat Biotech, India) are extremely popular in India against novel coronavirus. These vaccines are exported to Latin America, UK, Canada, Brazil and Mexico. Apart from that, BNT162b2 (mRNA vaccine, developed by Pfizer, Inc., and BioNTech), mRNA-1273 (mRNA vaccine, developed by ModernaTX, Inc.), JNJ-78436735 (Viral vector, developed by Janssen Pharmaceuticals Companies of Johnson and Johnson) are also applied against COVID-19 virus (Patel et al., 2020; Kaur and Gupta, 2020; Dong et al., 2020). As per WHO, the first mass vaccination programme started in early December 2020. Till now, $1.30 \%$ of world population fully vaccinated and among them $0.55 \%$ of Indian population fully vaccinated that reduced the death rate as well as actively infected people but again the death count shoots up in the recent month, 2021 and expected as second wave of COVID-19 virus in a new form which is stronger than former strain. Moreover, there are many controversial statements about the effectiveness of COVID-19 vaccine especially in terms of storage of the vaccine and some adverse effects such as soreness at the injection site after the first dose and fatigue, myalgia, arthralgia, headache, pain, and redness at the injection site $(2.0 \%)$ after the second dose (Kyriakidis et al., 2021) and people are scared to take vaccination but by the time world's lives completely dismantled through this gruesome situation and the proper rules and guidance for cope up the COVID-19 pandemic remains grossly unfulfilled. Therefore, an alternate method for increasing immunity through home remedies are achieved more concentration to fight against Covidvirus. Of late, boosting immunity through dry fruits is really fulfilling the thrust areas and plays a significant role in combating covid-19 virus infection. In this manuscript, such important edible dry fruits and seeds are listed and discussed about their role as immunomodulators and as well as antiviral properties with their responsible phytochemicals.

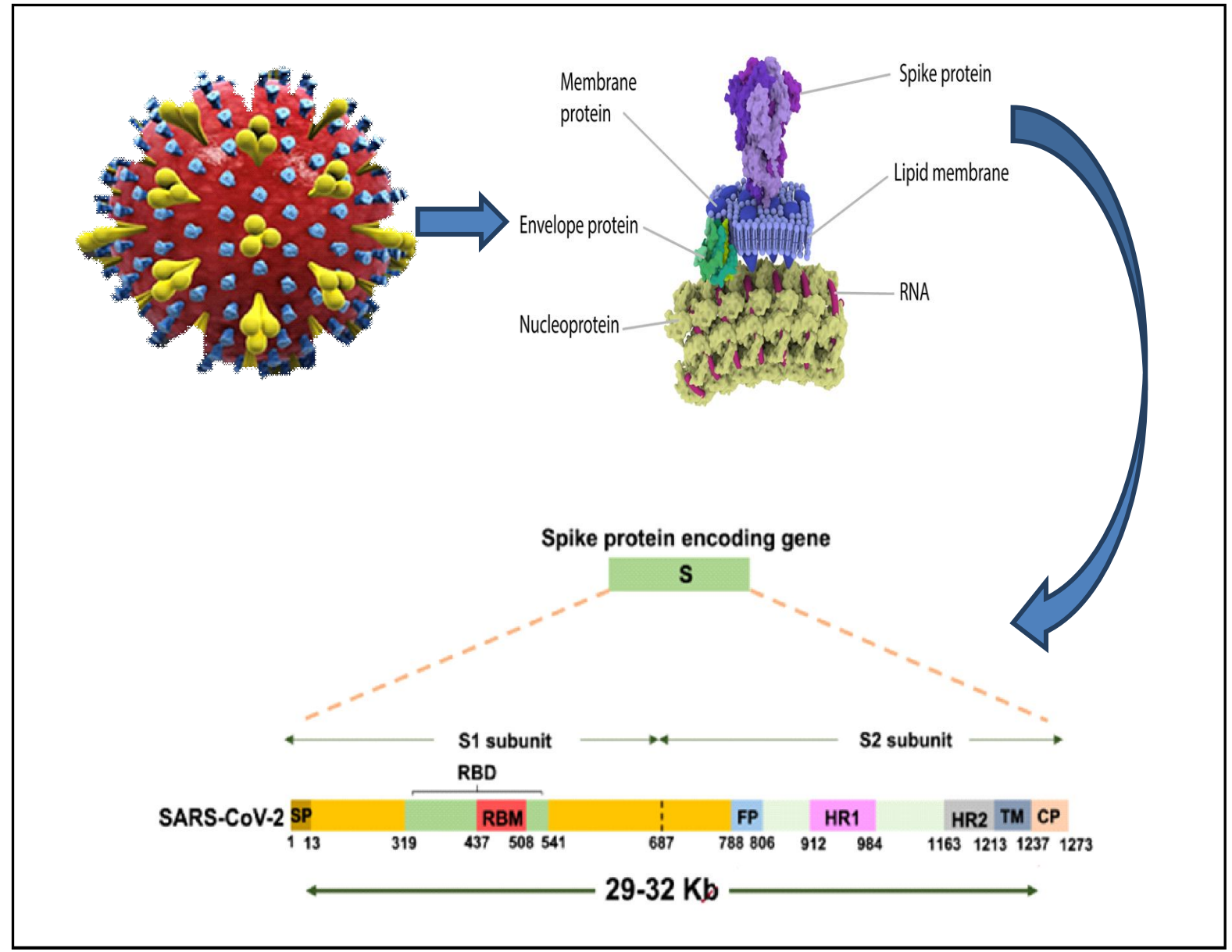

Figure 1: Genetic code of spike protein in novel coronavirus. 


\section{Methods}

The literature search was performed using many electronic databases, viz., EMBASE, PubMed and Google Scholar. Hand searching of the reference lists of the retrieved studies was performed to identify further relevant publications.

\section{Dry fruits}

Dry fruits and seeds contain same nutritional values like fresh fruits. Fresh fruits are generally perishable because of the presence of water or moisture. Even they are the source or favorable medium for development of microorganisms and for the progress of certain biochemical processes like fermentation, affected by various enzymes. Hence, for the stability of the fruits, the water content should minimum as the value should be from 18 to $23 \%$ that enabling their storage in ordinary conditions. Fruits are dried whole or sliced depending on their size. Plums, cherries, morello cherries, blueberries, blackcurrants and figs are dried whole whereas peaches, apricots are dried sliced.

Dry fruits or superfoods are always superior to other food items with respect to the nutritional value. The dry fruits contain abundant nutrition in form of nutrients, fibre, vitamins (Riboflavin, Vitamin
A-C-E-K-B6), minerals (calcium, copper, iron, magnesium, potassium, phosphorus, and zinc) and proteins. Not only that, they have some special characteristic or benefit in providing relief from some ailment or disease, enhances immunity, reduces blood pressure, sugar or cholesterol, any heart diseases and provides internal strength and stamina. Dry fruits just like berries and nuts are high on antioxidants and also nowadays use as dietary supplements (Beyhan et al., 2010). They are mostly used in confectionaries, bakery products and sweet industries. Even some are used in cosmetic industries as prevent ageing, reduce skin tanning, skin glowing effect by resistance of ultraviolet B(UVB), etc. (Sachdeva and Katyal, 2011; Li et al., 2020). Perhaps they are potent antiviral agents too. Many literatures revealed the antiviral efficacy of dry fruits (Nikolaeva-Glomba et al., 2014; MusarraPizzo et al., 2019) along with immunomodulatory activity which are more interest in the present COVID-19 situation to build up self immunity. Based on that, in this paper few important edible dry fruits and seeds are documented with their effects. The listed dry fruits and seeds are namely; almond, cashews, raisins, walnuts, pistachio, apricots, dates, peanuts, hazelnuts, sunflower seeds, pecans, chestnuts, prunes, dry figs, fox nuts, flax seeds, chia seeds, pumpkin seeds, betel nuts, and dry coconut (Table 1).

Table1: Dry fruits with their responsible phytochemicals

\begin{tabular}{|c|c|c|c|}
\hline Dry fruit name & Biological source & Important chemical constituents & Cultivation in India \\
\hline ALMOND & $\begin{array}{l}\text { Seeds of Prunus amygdalus } \\
\text { fruits } \\
\text { F: Rosaceae }\end{array}$ & $\underbrace{\mathrm{H}_{\mathrm{H}}^{\mathrm{H}}}_{\text {Stigmasterol }}$ & $\begin{array}{l}\text { In hilly states of Jammu and Kashmir } \\
\text { and Himachal Pradesh }\end{array}$ \\
\hline DATES & $\begin{array}{l}\text { Fruits of Phoenix dactylifera } \\
\text { F: Asteraceae }\end{array}$ & Caffeic acid & $\begin{array}{l}\text { Kachchh district of Gujarat, Punjab } \\
\text { and Rajasthan are major dates } \\
\text { growing states }\end{array}$ \\
\hline WALNUTS & $\begin{array}{l}\text { Fruits of Juglans nigra } \\
\text { F: Juglandaceae }\end{array}$ & Proanthocyanidin B2 & $\begin{array}{l}\text { Jammu and Kashmir, Uttarakhand, } \\
\text { Himachal Pradesh and } \\
\text { Arunachal Pradesh }\end{array}$ \\
\hline PEANUTS & $\begin{array}{l}\text { Nuts of Arachis hypogeal } \\
\text { F: Fabaceae }\end{array}$ & Coumaric acid & $\begin{array}{l}\text { Gujarat, Tamil Nadu, Andhra Pradesh, } \\
\text { Maharashtra, Karnataka, and } \\
\text { Rajasthan. }\end{array}$ \\
\hline
\end{tabular}




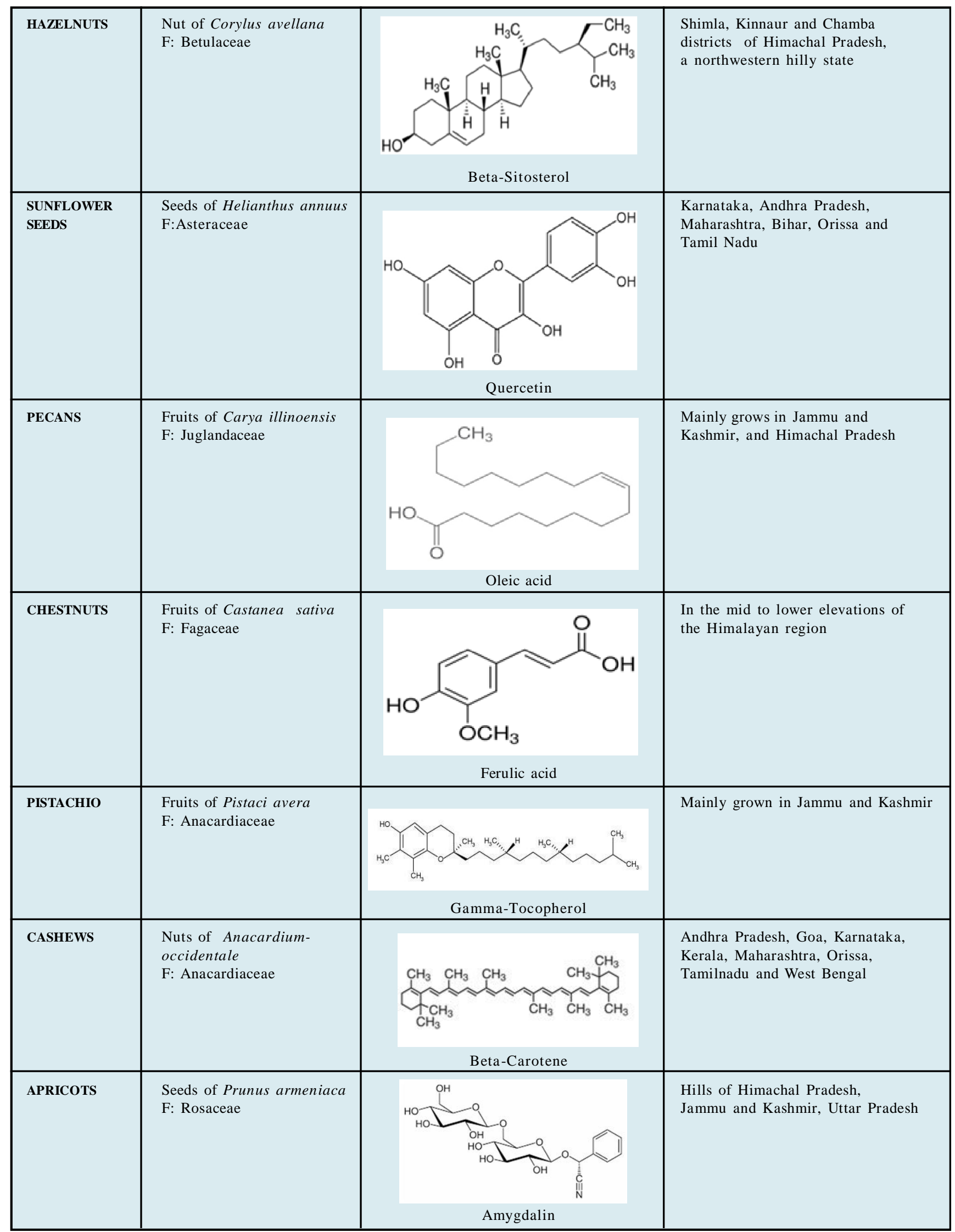




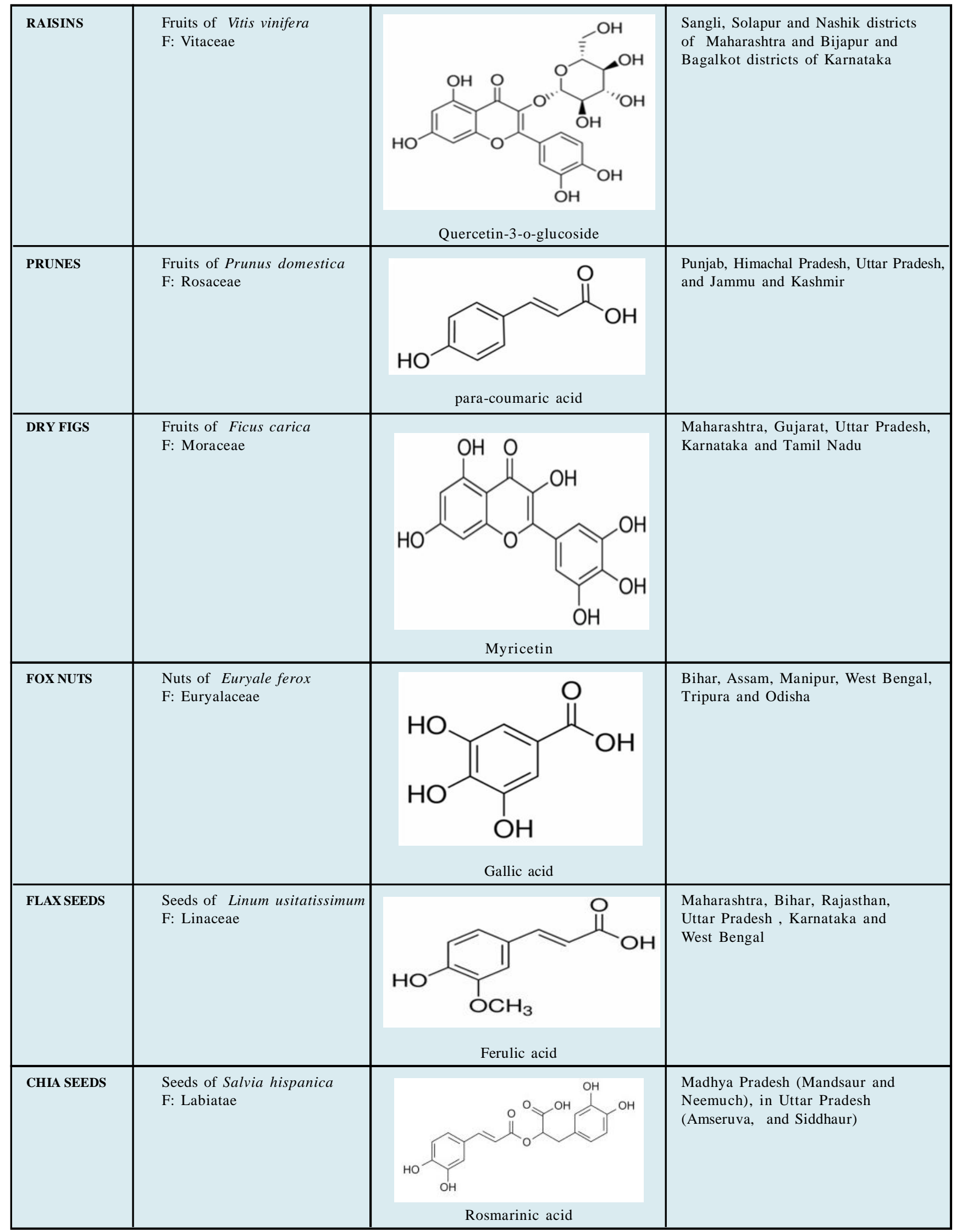




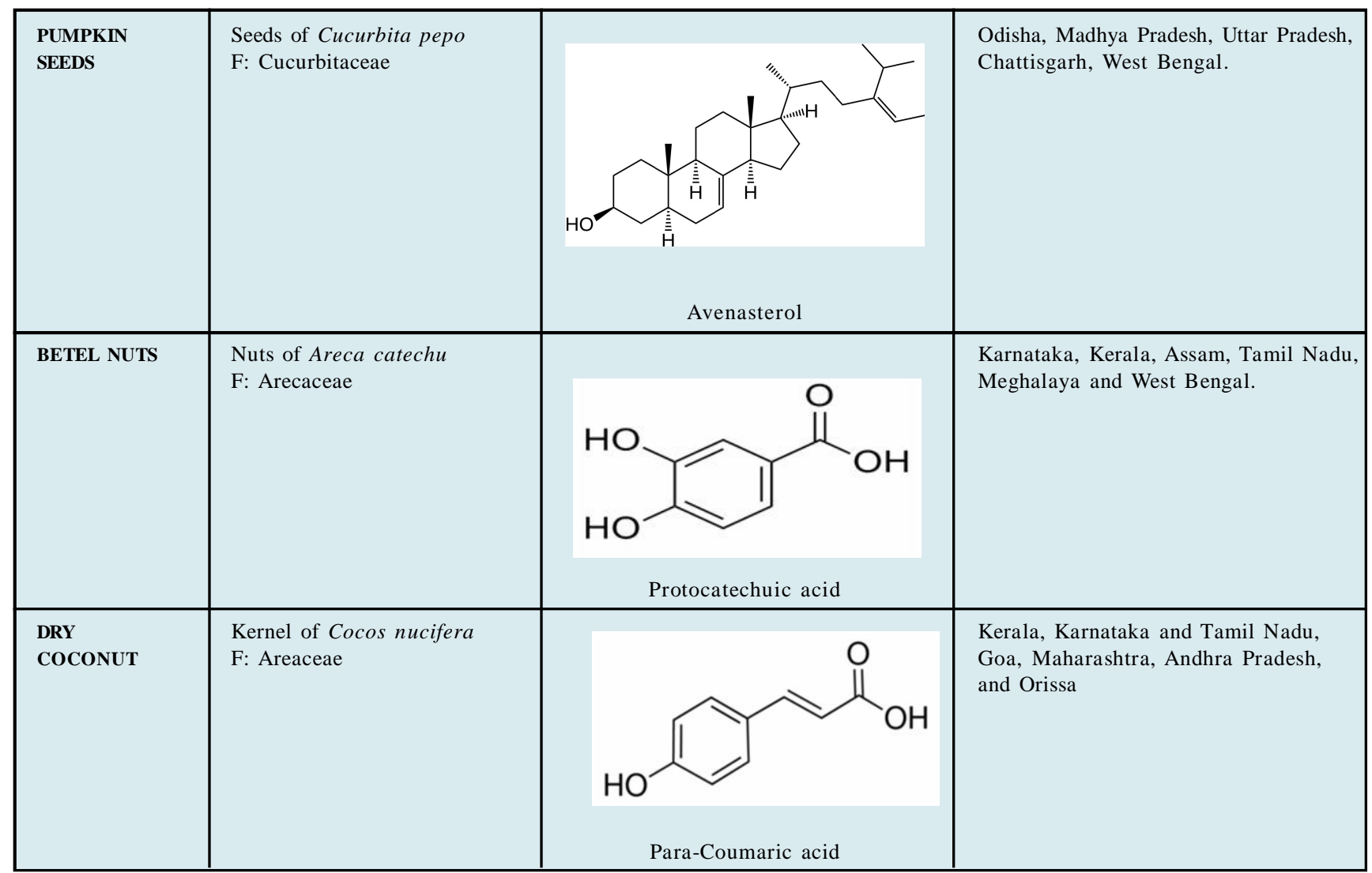

\subsection{Almonds}

Almonds are edible seeds, native to the Mediterranean region, mainly Iran (Figure 2). They are rich in protein, fibre, vitamin E, calcium, copper, magnesium and riboflavin. Because of presence of many essential phytoconstituents, especially phytosterols (campesterol, beta-sitosterol, 5-avenasterol and stigmasterol), they have rich antioxidants activity. They contain no dietary cholesterol and the high content of monounsaturated fatty acids (MUFAs) (Griel and KrisEtherton 2006). Hence, they are applied in many health-related issues like constipation, respiratory issues, heart disorders and strengthening of immune system (Richardson et al., 2009), besides it also applied in cosmetic field for hair, skin and teeth nourishment.

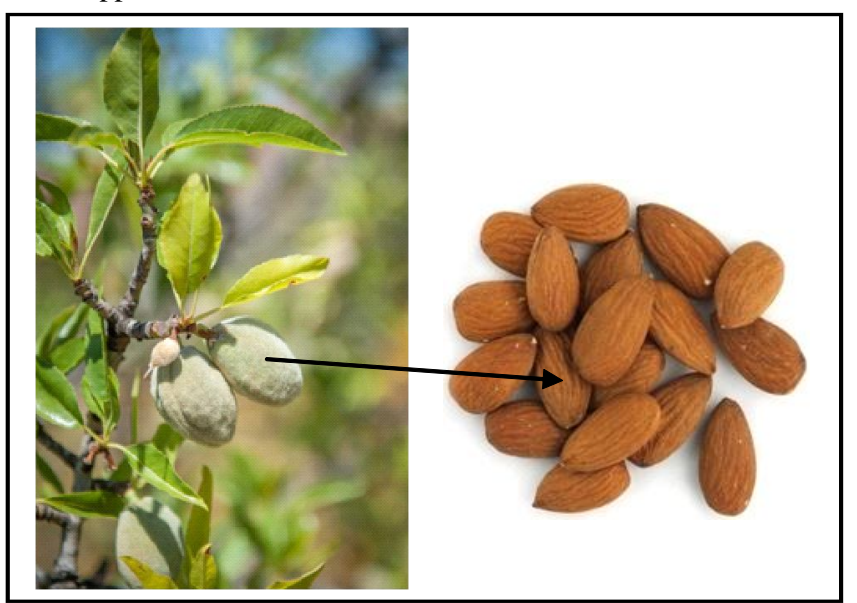

Figure 2: Almond nuts.
Due to presence of polyphenolics and flavonoids, they are strong antioxidant agents. Research literatures results the potent antioxidant activity of the fractions of almond aqueous extract due to the presence of isolated various polyphenols such as vanillic, caffeic, p coumaric, ferulic acids, quercetin, and kaempferol (Amarowicz et al., 2005; Oliveira et al., 2018). Earlier literature revealed high levels of cytokine production with almond seeds such as interferon- $\alpha$ (INF- $\alpha$ ), interleukins (IL-12), INF-gamma and tumour necrosis factor $(\mathrm{TNF}-\alpha)$. The seeds improve the immune surveillance of the peripheral blood mono nuclear cells towards viral infections. It significantly decreases in the Herpes simplex virus (HSV-2) replication and stimulates the immune response and helps in an antiviral immune defense (Arena et al., 2010; Mandalari et al., 2010). With its vital applications, during COVID situation, it is used as an ingredient in booting immunity and fighting against COVID-19 virus.

\subsection{Cashews}

Cashew is a tropical fruit native of South and Central America (Brazil) and grown well in the North and Northeast regions (Figure 3). The cashew nuts are rich source of vitamins E and B6. Apart from that, the nut also contains high amount of carbohydrates, proteins, phosphorous, iron, zinc, magnesium, fibers, and mono and poly unsaturated fatty acids. Apart from that, many phytoconstituents like alkaloids, flavonoids, saponins, tannins, steroils, mainly $\beta$ carotene, lutein, zeaxanthin, $\alpha$ tocopherol, $\gamma$ tocopherol, thiamin, stearic acid, oleic acid, and linoleic acid are present (Trox et al., 2010) 


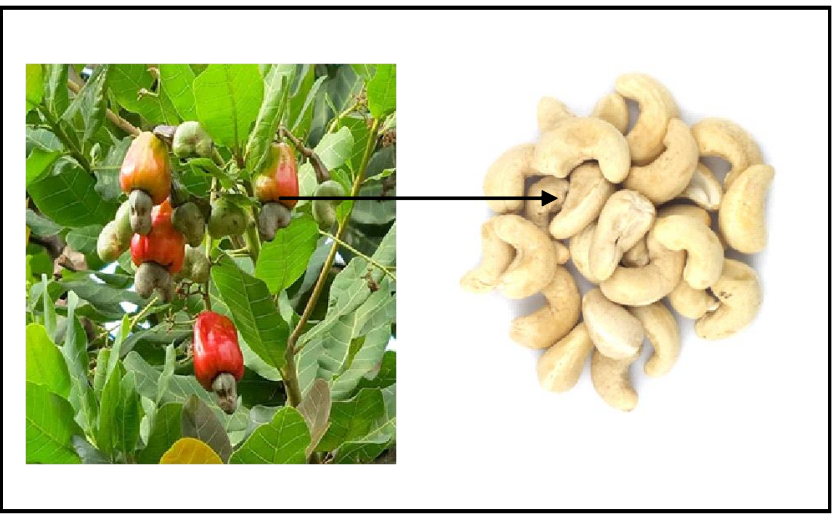

Figure 3: Cashew nuts.

Due to such plant constituents, it shows many medicinal activities especially, increase bone mineral density (Rivas et al., 2013), decreased risk of metabolic syndrome (Fernández Montero et al., 2013). It contains high number of polyphenols that shows antioxidant activity (Soares et al., 2013) and recently showed potent immunomodulatory activity (Mattison et al., 2020). It also shows significant antiviral activity against cowpea mild mottle virus on soybean (Andayanie et al., 2019). It is used to bring a rich texture and flavour to various dishes. It has commercial value due to its edible hypocarp and nutritious kernel. With its vital applications, it is used as an ingredient in booting immunity against COVID-19 virus.

\subsection{Raisins}

Raisins are dried grapes, made from dehydrated grapes (Figure 4). The grape is the native of North America. They are used in both sweet and savoury food preparations. They are good for health and have been known to reduce acidity and help in digestion. They contain micronutrients, vitamins, folate, potassium, magnesium, and also fibres. They are rich dietary source of flavonol glycosides, triterpenoids, phenolic acids, stilbenoid, flavonoids, proanthocyanidins, hydroxybenzoic acid. Caffeoyl tartaric acid (CTA) and quercetin 3-0-glucuronide are also present in high amounts.

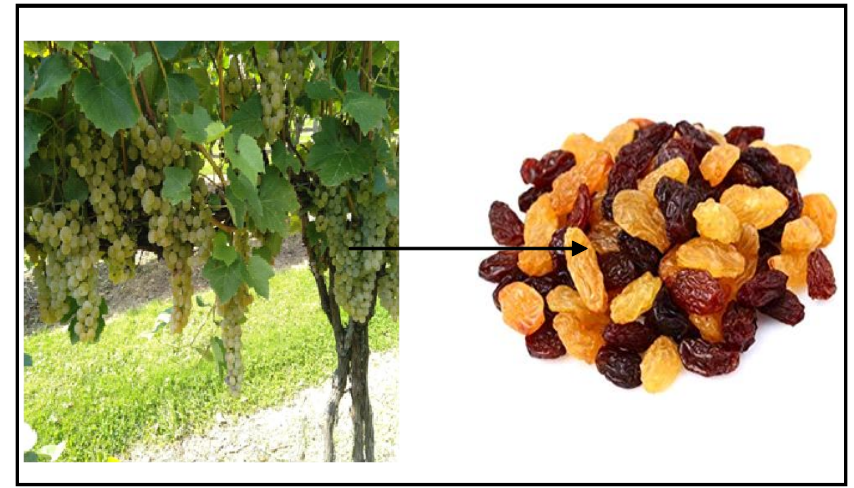

Figure 4: Raisins.

Many medicinal applications such as treatment of obesity and diabetes, gastric cancer prevention, dental decay reduction, and decrease in total cholesterol, and LDL cholesterol, etc., are reported with the presence of many phytochemicals in raisins (Jeszka-
Skowron and Czarczynska-Goslinska, 2020). Due to presence of polyphenols (flavanol, (+)-Catechin, phenol acid, transcaftaric acid, flavonol, quercetin-3-O-glucoside, anthocyanin and malvidin-3-O(6-O-p-coumaroyl-glucoside), they act as antioxidants in the body (Hardin-Fanning, 2008; Williamson and Carughi, 2010; Kelebek et $a l ., 2013)$. It also showed potent immunomodulatory activity by upgrade the secretion level of tumor necrosis factor- $\alpha$ (TNF- $\alpha$ ) in mice serum due to presence of proanthocyanidins (Tong et al., 2011). Significant antioxidant and antiviral activity are also reported for chloroform fraction against Herpes simplex virus type-1 (HSV-1) and Parainfluenza viruses (PIV) (Orhan et al., 2009). With its multiple medicinal applications, it is used as an ingredient in booting immunity against COVID-19 virus.

\subsection{Walnuts}

This shelled nutty delight is native to North and South America, southern Europe, Asia, and the West Indies. These nuts areextremely nutritious (Figure 5). There are two types of walnuts, viz., black or Persian and English walnuts. It is rich with Omega-3 fatty acids, dietary fibres, proteins, antioxidants, vitamins and minerals. Apart from that, bioactive compounds such as flavonoids, phenolic acid (ellagic acid), phenolic compounds (catechin), melatonin, folate, gamma tocopherol (vitamin E), selenium, juglone, phytosterols, and proanthocyanidin B2 (condensed tannin) are rich (Segura et al., 2006; Yang et al., 2009). But in comparison, the black walnut contains higher levels of monounsaturated fatty acids, polyphenols and $\gamma$-tocopherol than English walnut (Câmara and Schlegel, 2016).

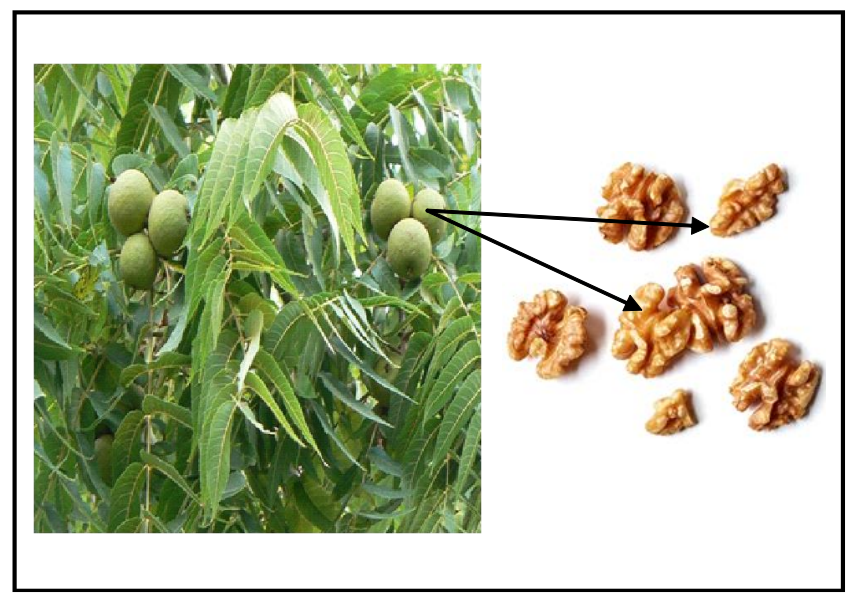

Figure 5: Walnuts.

It shows many medicinal or therapeutic efficacy due to the presence of essential bioactive compounds such as polyphenols promote neuronal calcium homeostasis in the striatum and hippocampus of the brain crucial for primary and secondary memory functions (Oliveira et al., 1997), carotenoids, alkaloids, nitrogen-containing or organosulfur compounds helps in direct neuroprotection (Willis et al., 2009). It has potent antiviral activity due to presence of juglone which was established by the computational method (Vardhini, 2014). Potential immunomodulatory activity and antioxidant activities are reported for walnuts (Soussi et al., 2018). The immunomodulatory activity of walnuts are determined for oligopeptides via innate and adaptive immunity, spleen $\mathrm{T}$ lymphocyte subpopulations, serum cytokine and immunoglobulin levels and result revealed significant improvement of humoral and 
cell-mediated immune responses, macrophage phagocytosis and natural killer cell activity (Mao et al., 2020).

\subsection{Pistachios}

Pistachios are native of Central Asia, especially in Iran, United States, and Mediterranean countries. They are edible fruits, important source of energy (Figure 6). They contain nutrients, minerals (sodium, calcium, phosphorus, iron, magnesium), antioxidants (tocopherols, carotenes, lutein, selenium, flavonoids), fibres, phytoestrogens (5,6beta-carotene, alfacarotene, and cryptoxanthin) and vitamins (VitA, Vit-B6) (Ghaseminasab et al., 2015).

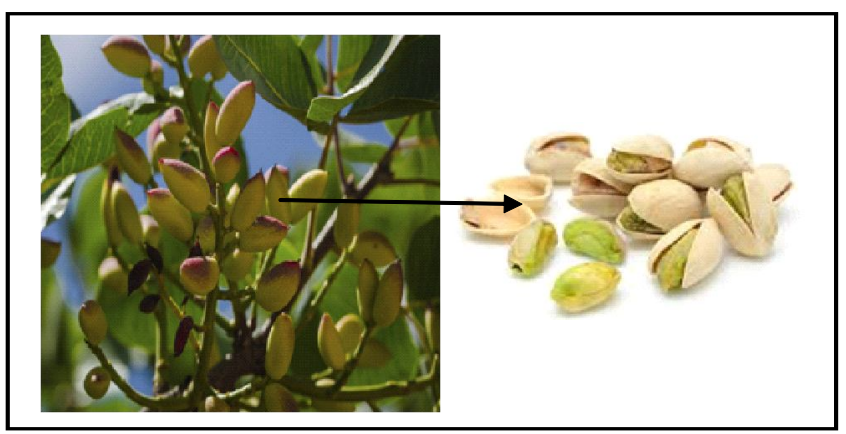

Figure 6: Pistachio fruits.

Due to presence of many essential chemicals, they have multiple health benefits and shows versatile therapeutic applications. It boosts the immunity with the rich source of vitamin B6 and some minerals such as zinc, copper, iron, selenium, and folate. The fruits showed potent antioxidant activity due tom the presence of polyphenols especially, tocopherols, gamma tocopherol (Gentile et al., 2007; Taghizadeh et al., 2018). They also have bioactive compounds like flavonols, flavanones, isoflavons, flavan-3-ols, proanthocyanidins and anthocyanin, phenolic acids and stilbenes. They are effective for the heart as they lower the bad cholesterol level (Casas-Agustench et al., 2011). They also help to prevent diabetes and boost immunity. Antiviral activity of pistachio extracts (Pistaciavera L.) was reported by resists the Herpes Simplex Virus 1 (HSV-1) replication due to the presence of polyphenols (Musarra-Pizzo et al., 2020).

\subsection{Apricots}

Apricots are belonging to genus Prunus, native to Asia especially in China, and are hugely popular in Middle Eastern countries, with Turkey and Iran. They are also known as stone fruitbecause the single seed is enclosed in a hard, stony shell (Figure 7). They are rich in fibres, and are a good source of vitamin A, C, E and copper. Apart from that, it contains minerals especially potassium, iron, magnesium and Phosphorus (Gupta et al., 2018).Vitamin E, like all anti-oxidant vitamins (A and $\mathrm{C}$ ), is vital in protecting the cells from damage caused by free radicals. Dried apricots are good for the skin, eyes and the immune system.

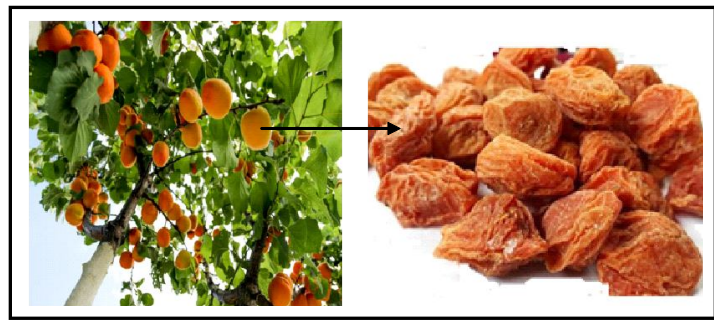

Figure 7: Apricot fruits.
The fruit contains carotenoids, flavonoids like quercetin-3-rutinoside, quercetin-3-galactoside and quercetin-3-glucoside.It shows many therapeutic efficacies especially antiparasitic, anticancer, antiaging, antiatherosclerating, antianginal, cardioprotective, hepatoprotective, renoprotective, antitussive, antiinflammatory, antinociceptiveand antioxidant due to the presence of beta-carotene (Sharma et al., 2014; Minaiyan et al., 2014). Apricot shows potential antioxidant activity due to the presence of beta carotene, ascorbic acid and polyphenols (Wani et al., 2017). The antiviral potential of apricot extract reported against herpes simplex virus type 1 (HSV 1) and type 2 (HSV 2), enveloped DNA viruses due to the presence of higher content of phenolics (Nishide et al., 2019). Thereafter, ethanolic apricot seed extract showed potent antiageing and immunomodulatory effect due to presence of amygdalin (Ramadan et al., 2020).

\subsection{Dates}

Dates are the one seeded fruitobtained from dates palm trees. The plant is native to Persian Gulf area (Iran), mainly grown in the Canary Islands, northern Africa, the Middle East, Pakistan, India, Mexico, and the U.S. state of California (Figure 8). They are used in different types of sweet dishes and can also be consumed on their own. The dry fruit is rich in vitamins (Vitamins B-complex and C), proteins, minerals (selenium, copper, potassium, and magnesium) and natural sugar (fructose and glucose) (Al-Farsi and Lee, 2008). The plants are naturally wind pollinated. Dry dates are used as a snackfood, in sweet and savory dishes, and in many dessert items.

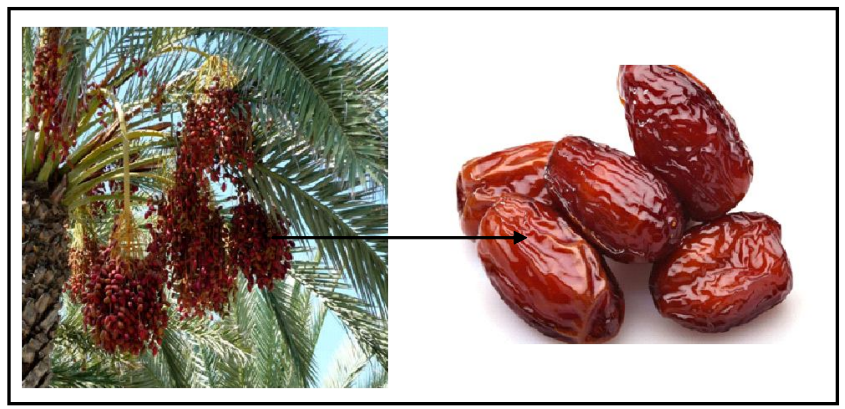

Figure 8: Date fruits.

Date fruits show many therapeutic activities, viz., antioxidant, antimutagenic, anti-inflammatory, gastroprotective, hepatoprotective, nephroprotective, anticancer, immunestimulant activities, etc., due to presence of flavonoids, and phenolic compounds (Tang et al., 2013). Antioxidant activity of dates is reported with the presence of flavonoids and phenolic contents (Biglari et al., 2008). It shows immunomodulatory activity with the presence of phenolic compounds (Hasan et al., 2010). It also shows potent antiviral activity by inhibited the infectivity of Pseudomonas phage ATCC 14209-B1 and prevented bacterial lysis (Jassim and Naji, 2010).

\subsection{Peanuts}

Peanut or "groundnuts" are the edible seeds of a legume (Pea family), belongs to the native to tropical South America (Figure 9). It is an annual herbaceous plant. They are rich in protein, oil, monounsaturated fat and fibers and are widely used for production of peanut butter, confections, roasted peanuts, snack products, soups and desserts. It has antioxidant activity and anti aging property due to the presence of resveratrol. It contains various bioactive compounds such as flavonoids (catechin, epicatechin, apigenin, and luteolin), 
carotenoids, phenols (p-coumaric acid), and phytosterols (alphaand beta-Carotene, beta-cryptoxanthin, lutein, and zeaxanthin) (Oliver-Chen and Blumberg, 2008).

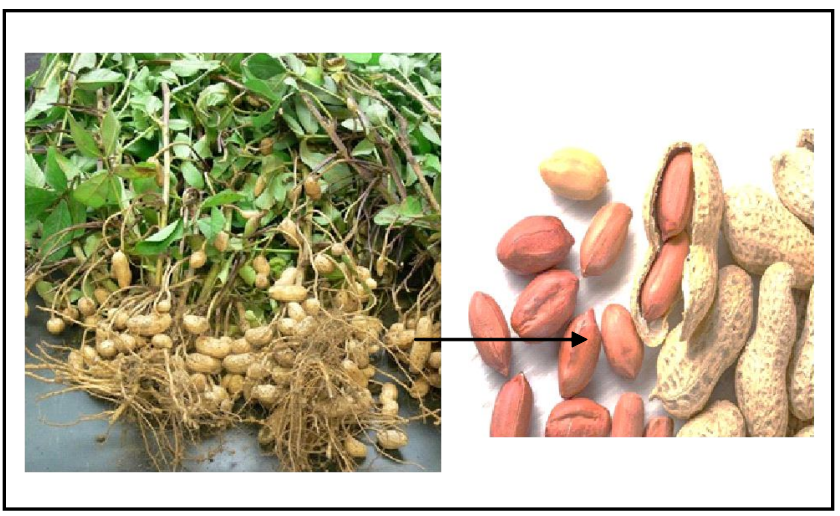

Figure 9: Peanuts.

Due to presence of vitamin E, caffeic, coumaric acid, flavonoids, stilbenes and polyphenolic compounds, it shows powerful antioxidant activity (Limmongkon et al., 2017).

With the presence of resveratrol, it shows immunomodulatory activity. The antiviral activity of ethanol extracts of peanut skins was evaluated against various influenza viruses using cell-based assays and affirmed the activity due to the presence of high content of polyphenols (Makau et al., 2018).

\subsection{Hazelnuts}

Hazelnuts are a member of genus Corylus, of hazel deriving from species avellana. It is very expensive nut and needs cold and hilly terrain. The tree nut is native to Europe and western Asia (Figure 10). It is a deciduous treewith attractive flowers. It contains rich source of proteins, carbohydrates, unsaturated fatty acid (mainly Oleic acid), dietary fibre, vitamins (vitamin E, B1, B2 and B6 complex), minerals (potassium, phosphorus, calcium, magnesium, boron, copper, manganese and selenium) and other fatty acids like palmitic acid, steracic acid, linoleic acid and linolenic acid (Kornstriner et al, 2013). It also contains many essential amino acids namely; amino acids like glutamic acid, arginine, alanine and aspartic acid, etc. Due to presence of the minerals, it maintains healthy nerve function and balanced body system (Ozkutlu et al, 2011).

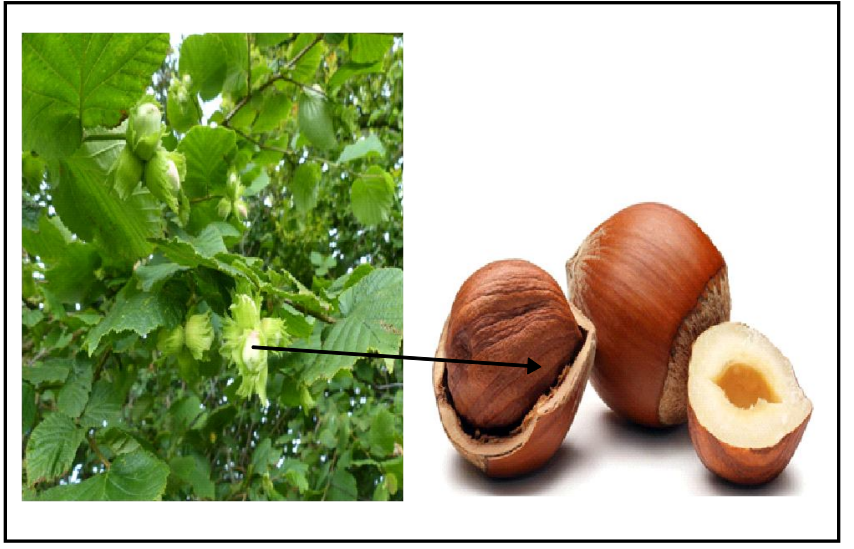

Figure 10: Hazelnuts.
Various bioactive compounds such as tocopherols (alpha-tocopherol), phytosterol (beta-sitosterol, squalene), phenolics (mono and oligomericflavan-3-ols), filbert (principal flavor compound), flavan$3 \mathrm{ol}$, anthocyanins, isoflavones, etc., are present. Antioxidant activity of fresh or dry hazelnuts was evaluated due to presence of content of polyphenols and tocopherols (Arcan and Yemenicioglu, 2009; Pycia et al., 2020).

\subsection{Sunflower seeds}

The seeds are mainly the fruits of the sunflower plant, situated inside the round flower head. The perennial plant is mainly the native of North and Central America. Seeds are used as snack, as a confectionary nut, salad garnish and mainly for oil production. Seeds contain protein, unsaturated fats, fiber, essential amino acids (phenylalanine and tyrosine, leucine, methionine, cysteine), vitaminE, selenium, copper, zinc, folate, iron, etc. Edible seeds are also rich in poly unsaturated fatty acids (approximately $31.0 \%$ ), flavonoids, phenolic acids (Pasko et al., 2009). Traditionally, the seeds are used for the treatment of bronchial, laryngeal and pulmonary infections, coughs and colds and in whooping cough (Bashir et al., 2015).

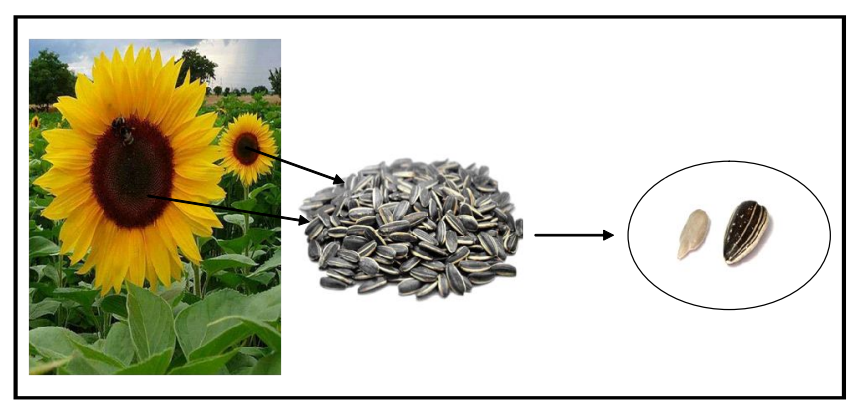

Figure 11: Sunflower seeds.

The main bioactive components are flavonoids (heliannone, quercetin, kaempferol, luteolin, apigenin) and phenolic acids (caffeic acid, chlorogenic acid, caffeoylquinic acid, gallic acid, protocatechuic, coumaric, ferulic acid, and sinapic acids), polyunsaturated fatty acids, and vitamins (Kamal, 2011) and due to presence of these constituents, the seed shows versatile therapeutic applications, viz., antioxidant, antimicrobial, anti-inflammatory, antihypertensive, wound-healing, and cardiovascular actions. The seeds show immune boosting activity with the presence of high content of selenium mineral and vitamin $\mathrm{E}$. Due to presence of phenolic compounds, it showed potent antioxidant capacity (Giada and Mancini-Filho, 2009). Other literature also revealed high antioxidant potential of sunflower seed with the presence of polyphenols (e.g., caffeic, chlorogenic, caffeoylyquinic, sinapic, ferulic, gallic, coumaric, and protocatechuic acids) (Pająk et al., 2014).

\subsection{Pecans}

Pecan nuts are the seeds, native to North America (Mexico) and the southern United States in the region of the Mississippi River (Figure 12). The seeds are rich in fats (unsaturated or saturated fatty acids),source of thiamine, folate, niacin, riboflavin and vitamin B6, as well as minerals like calcium, iron, magnesium, phosphorus, and zinc. Oleic acid is the most significant mono unsaturated fatty acid, others constituents like oleic acid and linoleic acid are also present. It contains also a dietary source of alpha-tocopherol, gamma-tocopherol and squalane. 


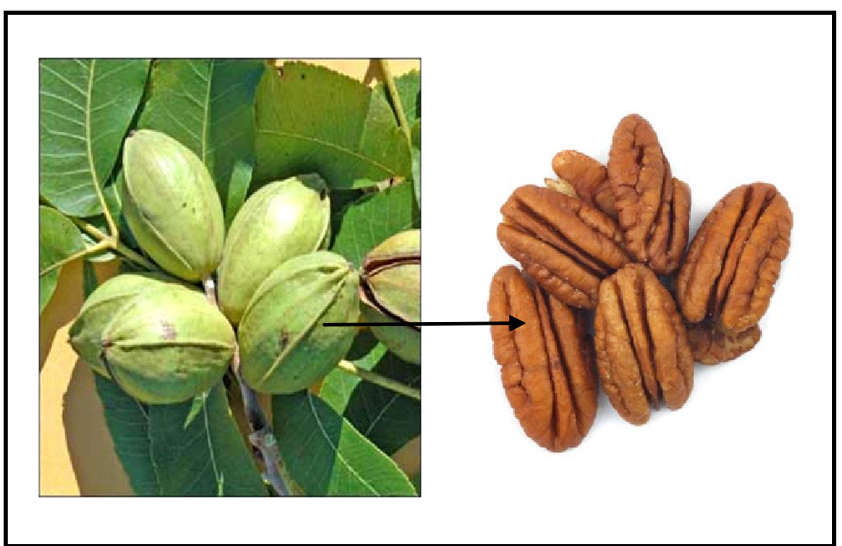

Figure 12: Pecan nuts.

Bioactive constituents like sterols (campesterol, stigmasterol, betasitosterol), phenolic acids, favonoids, glycosylated phenolic acids, glycosylated favonoids and (epi) catachin are present. Due to these active constituents, it showed antimicrobial as well as antioxidant activities (do Prado et al., 2014). It also showed potent antiviral activity due to the presence of phenolics in pecan kernels (Flavan-3ol, anthocyanidins, proanthocyanidins and phenolic acid). It reduces the risk of developing cancer, diabetes, cardiovascular disease and Alzheimer's disease with the presence of abundant polyphenolic compounds (Li et al., 2014).

\subsection{Chestnuts}

There are four different types of chestnuts, namely; American, European, Japanese and Chinese chestnuts. European chestnut is also known as sweet chestnut, native to Southern Europe, Western Asia and North Africawhereas American chestnuts are native to the Appalachian forests of the United States from Maine to Georgia (Figure 13). The nut containsmainly carbohydrates (mostly in starch and sucrose form), mineral nutrients $(\mathrm{Ca}, \mathrm{Mg}, \mathrm{P}$ and $\mathrm{K})$, other essential fatty acids, several vitamins (vitamin C, E, thiamine, riboflavin, niacin, pyridoxine, folate) (Aguilar et al., 2016). They are use in inflammation and swelling, bacterial infections, diarrhea and cardiovascular disorders.

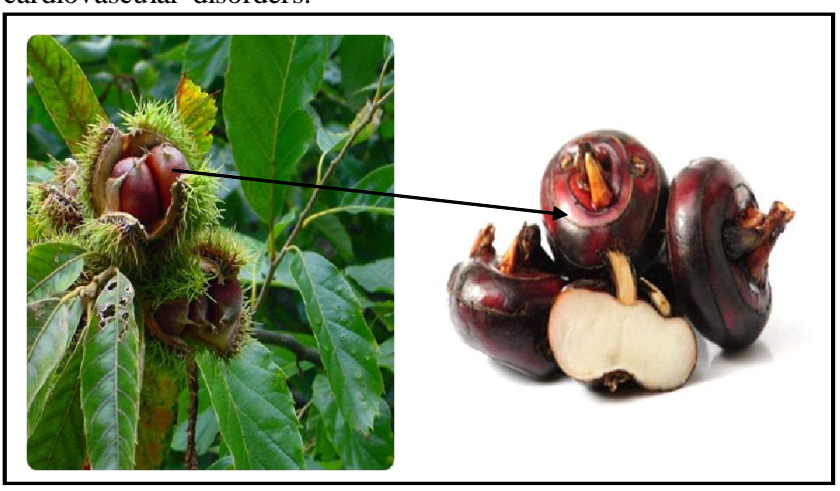

Figure 13: Chestnuts.

The main bioactive components such as phenolic compounds in terms of phenolic acids (Ellagic and gallic acids), flavonoids (quercetin derivates), and tannins are present in nuts (Braga et al., 2015). In vitro antiviral activity against human viruses (avian reovirus and avian metapneumovirus) was revealed by MTT assay with the presence of tannins in the nuts (Lupini et al., 2009). The extracted nut shell showed potent immunomodulatory activity using blood and intestinal leukocytes of Oncorhynchus mykiss models with the presence of phenolic compounds (Coccia et al., 2019). Due to presence of phenolic constituents, they are microbial resistant and potent antioxidant (Silva et al., 2020).

\subsection{Prunes}

Prunes are dried plums, contains high dietary fibre. It is native to Europe, Asia and America. Mainly two species like, European plum and the Japanese plum are commercial significant across the globe. Fruits are medium size, globose to oval and the flesh is firm and juicy (Figure 14). It contains carbohydrate, protein, fats, minerals $(\mathrm{Ca}$, $\mathrm{Mg}, \mathrm{P}, \mathrm{K}, \mathrm{Zn}, \mathrm{Cu}$ and $\mathrm{Mn}$ ), vitamins (Vitamin A, B1, B2, B3, B5, B6, E and K), carotenoids, etc. It also has sugar alcohol sorbitol and phenolic compounds, predominantly chlorogenic and neochlorogenic acids (Stacewicz Sapuntzakis et al., 2001). Traditionally, it is used as a remedy for constipation.

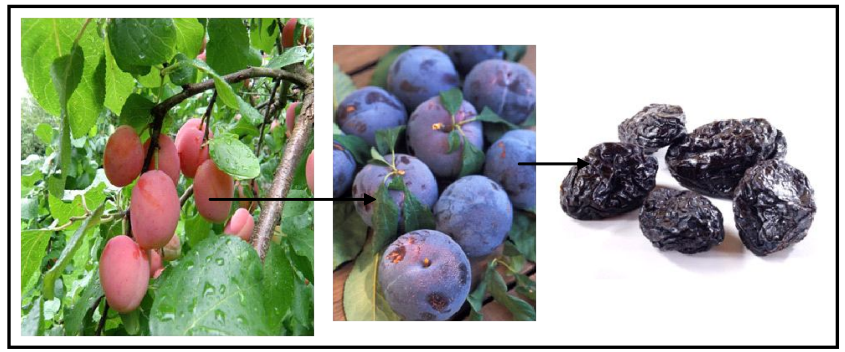

Figure 14: Prune fruits.

Many bioactive components are also present and due to that it shows many therapeutic activities. It contains polyphenolic compounds (chlorogenic acid, neochlorogenic acid, caffeic acid, coumaric acid) and flavonoids (rutin, proanthocyanidin) which shows anticancer and antioxidant activity (Madaru et al., 2010). It shows effective antiviral action against HIV-1 (Oh et al., 2011). Apart from that dry prunes also contain benzaldehyde, 2-furancarboxyaldehyde and ethyl cinnamate. It also shows potent immunomodulatory activity due to the presence of protocatechuic acid (water soluble monomeric phenolic acid) (Rasne et al., 2018).

\subsection{Dry figs}

Fig is one of the tropics and subtropics area fruit. The fruit is hollow and fleshy structured (Figure 15). It is native to southwest Asia and the Mediterranean region (Afghanistan, Portugal). The fruit is having economic importance and also eaten as bushfood. Dry figs contain high amount of protein, lipids, dietary fiber, minerals $(\mathrm{Cu}, \mathrm{Mg}, \mathrm{K})$, vitamins (riboflavin, thiamine, B6, K) and sugars. It contains many important phytoconstituents, viz., phenolic compounds (gallic acid, chlorogenic acid), flavonoids (rutin, quercetin-3-O-rutinoside, epicatechin) (Vinson, 1999).

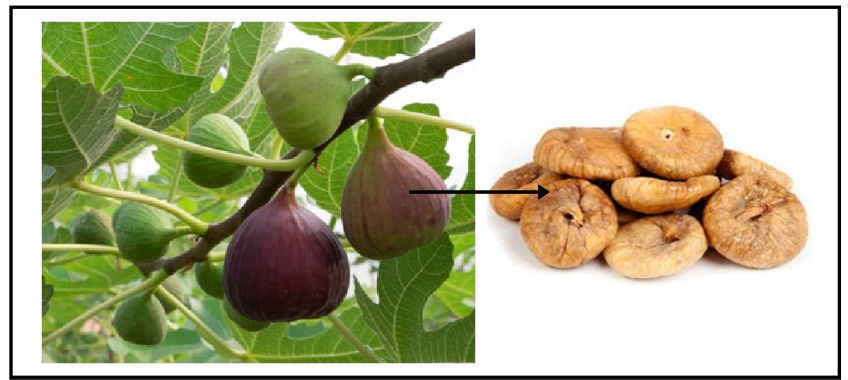

Figure 15: Dry figs. 
Due to presence of versatile phytoconstituents such as alkaloids, flavonoids, terpenes, saponins, coumarins, sterols, and terpenes, it shows multiple therapeutic action. It shows highest antioxidant activity due to the presence of polyphenols, flavonoids and anthocyanins (Caliskan and Polat, 2011). The latex of fig fruits showed potent antiviral action against human viruses (caprine herpesvirus1) (Camero et al., 2014). Immunomodulatory action of fermented fig fruits is revealed due to the presence of coumaric acid, aconitic acid, and polyphenols (Zhao et al., 2020).

\subsection{Fox nuts}

Fox nuts are aquatic nut, commonly known as makhana or gorgon nut or prickly water lily. One fox nut plant produces more than 100 seeds which contains mainly essential amino acids. The seeds are used as stuffy dish. Roasted fox nuts are also used as snacks. It is native to tropical and subtropical regions of South East and East Asia (Figure 16). It has rich source of carbohydrate, proteins and minerals (mainly Fe).

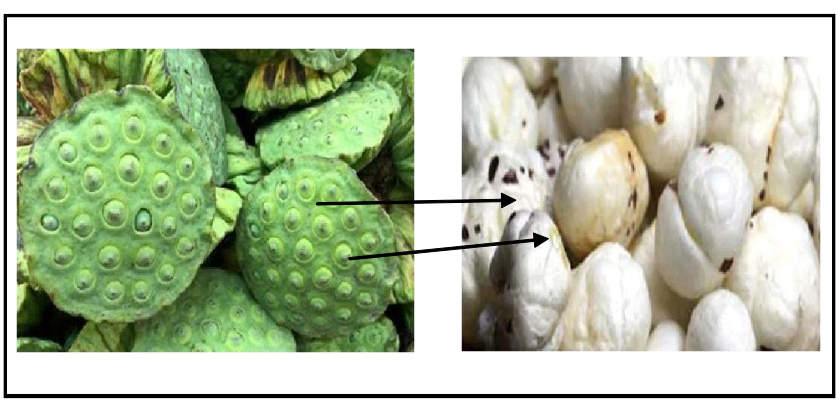

Figure 16: Dried fox nuts.

Apart from these constituents, many other bioactive components are also available like flavonoids (mainly kaempferol), phenols, ascorbic acid, sugars. Due to presence of many phytochemicals, it is used as antidiabetic, antioxidant activities (Song et al., 2011).

\subsection{Flax seeds}

Flax is an annual herbaceous plant, native to southern Mexico and northern Guatemala. The seeds are consumed grounded or as whole grain in fruit juices, milk, in refreshing drinks and salads (Figure 17). It has high content of polyunsaturated fatty acids especially, alpha-linolenicacid,linoleic acid, oleic acid, minerals, proteins, and dietary fiber (soluble flaxseed fiber mucilage- d-Xylose, L-Galactose, L-Rhamnose, d-galacturonic acid), etc. ( Porras-Loaiza et al., 2014).

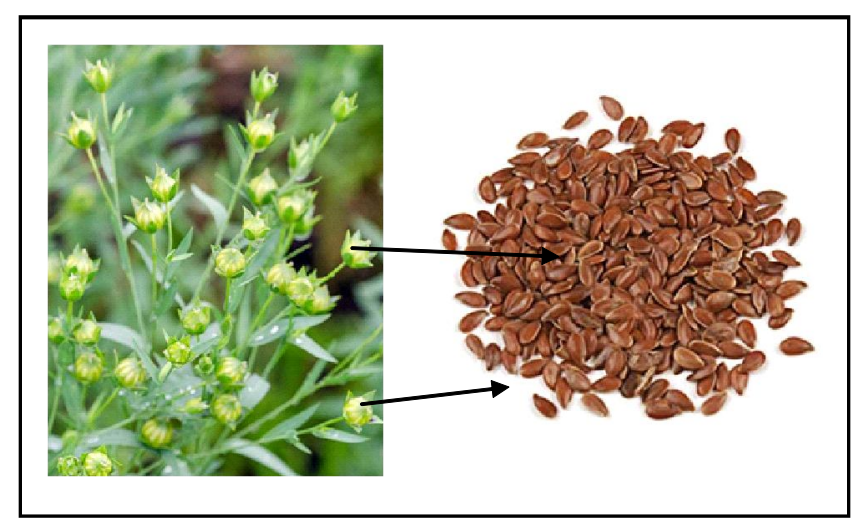

Figure 17: Flax seeds.
It contains the main bioactive compounds such as lignans (secoisolariciresinol-diglycoside (SDG), cyanogenic glycosides (linamarin, linustatin, neolinustin). Immunomodulatory activity of flaxseed extract was evaluated with the presence of phenolics (Kasote et al., 2012). Potent antioxidant activity of flax seed reported due to presence of ferulic acid and butylated hydroxyl toluene (SlavovaKazakova et al., 2016).

\subsection{Chia seeds}

Chia seeds are very small seeds, black oval shaped, belongs to mint family. They have high nutritional and medicinal values (Figure 18). The plant is native of Southern Mexico and Northern Guatemala. They have omega-3 fatty acids, polyunsaturated fatty acids, dietary fiber, proteins, vitamins (Vitamin A, B1, B2, niacin, K, E and D) and important minerals $(\mathrm{Ca}, \mathrm{P}, \mathrm{K}, \mathrm{Mg})$.

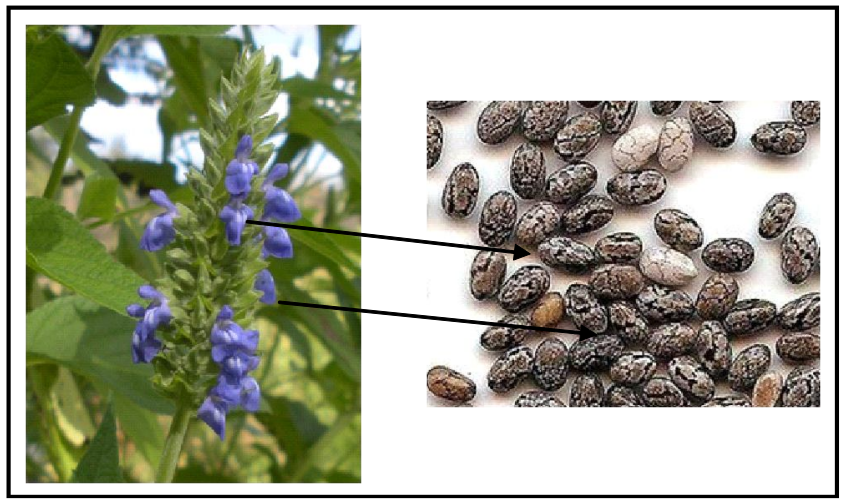

Figure 18: Chia seeds.

They have important bioactive compounds like polyphenols, antioxidant compounds like caffeic acid, rosmarinic acid, myricetin, quercetin, isoflavones like daidzein, glycitein, genistein, etc. Due to presence of the important phytoconstituents, they are used in reducing heart disease, diabetes, anticancer, hypotensive, etc. It shows antioxidant activity due to presence of phenolic acids and isoflavones (Martinez-Cruz and Paredes-Lopez, 2014). Immunomodulatory activity of hexane extract of chia seed was evaluated on phagocytosis and stimulation of neutrophils (Gayathiri et al., 2017).

\subsection{Pumpkin seeds}

Pumpkins are gourd family, native to Central America and Mexico. The seeds are flat, asymmetrically oval, inside kernel is light green colour (Figure 19). The seed contains mainly oil (mostly linoleic and oleic acid), minerals (particularly, phosphorus, potassium, magnesium, calcium, iron, zinc), proteins and amino acids, carbohydrates (6-10\%), and vitamins (thiamine, riboflavin, niacin, pyridoxine, and pantothenic acid).

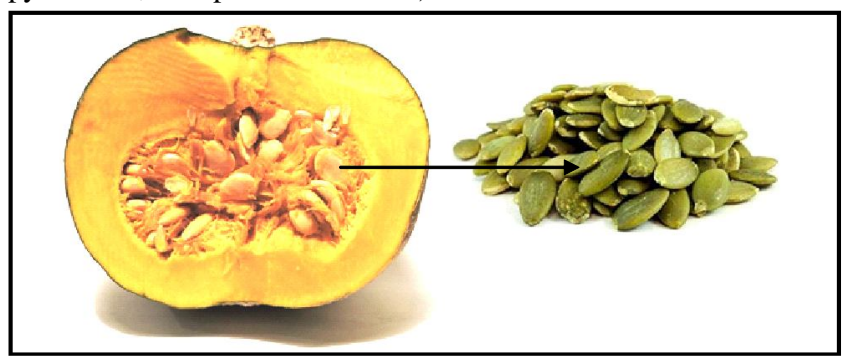

Figure 19: Pumpkin seeds. 
Apart from that, it contains many phytochemicals, namely; alkaloids, glycosides, carbohydrates, fixed oil and fats, phytosterols, saponin, phenolic compounds, tannins, proteins, amino acids, gums, and mucilage. The constituents are "7 sterols (avenasterol and spinasterol) and " 5 sterol (sitosterol and stigmasterol) are also present in the seed. Because of the presence of high content of phenolic and flavonoids, it shows potent antioxidant activity (Pal et al., 2018). Because of the presence of many active principles, it shows various therapeutic activities such as in treatment of sore chests, hemoptysis, bronchitis, in the management of benign prostatic hyperplasia and fever. It modulates immunobiochemical pathways induced by interferons (Acosta-Patiño et al., 2001). Due to presence of flavonoids, it has significant antioxidant capacity (Abdel-Rahman, 2006).

\subsection{Betel nuts}

Betel nuts are also known as areca nut is a type of seed of Areca palm. It is hard, rounded, and grayish in colour (Figure 20), native to West Indies. It grows in tropical Pacific, Southeast and South Asia and East Africa. The nuts are chewed with betel leaf shows mild stimulant effect. It has protein, little fibers, fats, carbohydrates, minerals like $\mathrm{Ca}, \mathrm{K}, \mathrm{Fe}$, etc. The areca nut contains the tannins, namely; arecatannin and gallic acid, terpineol, flavonoids, lignin and three main alkaloids, viz., arecoline, arecaidine and guvacine. Arecoline helps in increased stamina.

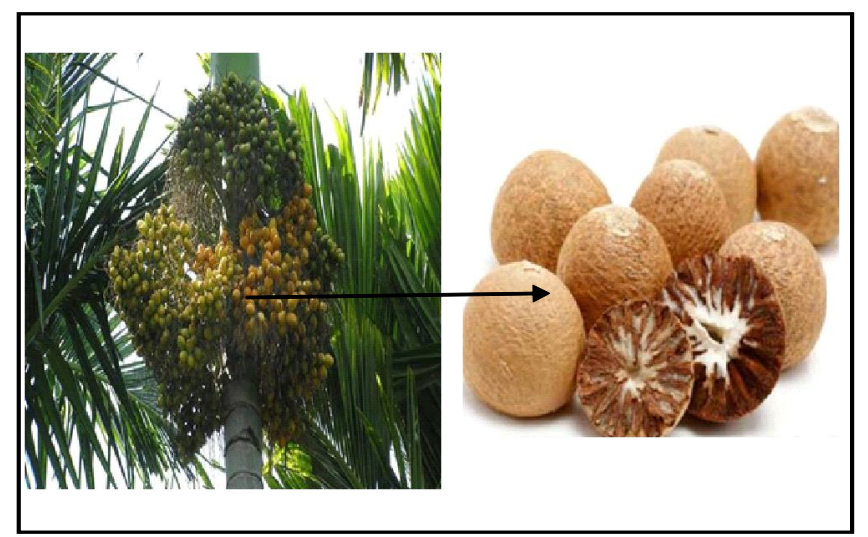

Figure 20: Betel nuts.

Methanolic extract of betel nut was evaluated for antioxidant activity with the presence of phenolic and flavonoid compounds (Hamsar $e t$ al., 2011). The ethanol extract of areca nut was evaluated for immunomodulatory activity and revealed potent immune boosting property due to the presence of catechin and quercetin (Sari et al., 2020).

\subsection{Dry coconut}

It is the coconut fruit when the milk within coconut hardens with its maturity; it becomes the copra and known as dry coconut (Figure 21). It is off-white to white in color. The coconut tree is a palm tree family, native of the Malay Archipelago or the South Pacific. Dried coconut has more calories than fresh one, rich sources in saturated fats, dietary fibers, sugars, and minerals $(\mathrm{Na}, \mathrm{K}, \mathrm{Fe}$ and $\mathrm{Ca})$.

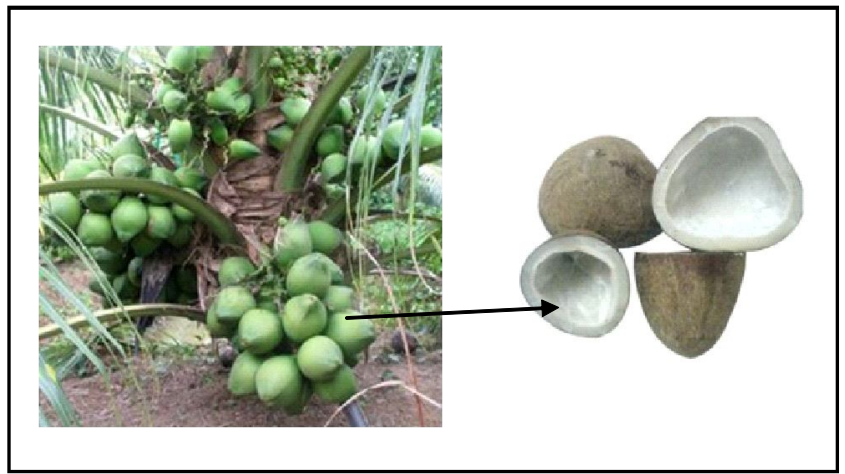

Figure 21: Dry coconut.

It has rich sources of many active constituents like phenols, flavonoids, glycosides, tannins, alkaloids, and saponins. Antibacterial and immunomodulatory activity of coconut protein was investigated by immune suppressed with cyclophosphamide (Geo Vigila and Baskaran, 2008). Due to presence of these constituent especially tocopherols, tocotrienols and phenolics, it shows powerful antioxidant property (Prakruthi et al., 2015; Prakruthi et al., 2016).

\section{Discussion}

The present article provides a proper information about the nutritional values, multiple bioactive components, scientific literatures imparting versatile therapeutic applications. Especially antioxidant, immunomodulatory and antiviral activities of dry fruits and seeds are reported with the presence of high content of flavonoids, phenolics, sterols. Therefore, the manuscript is the current focus for the basic utilization during the covid situation for boosting the immunity and fights against covid virus. Many literatures are reviewed and based on the significant medicinal properties, twenty important dry fruits and seeds are selected and their significant role in human health are discussed. All the selected edible dry fruits and seeds are showed potent antioxidant activities which plays important role in combating viral infection through body defense mechanism.

\section{Conclusion}

The herbal remedies are the best solution that are employed for the treatment and management of various chronic health disorders. Dry fruits and dried seeds are used traditionally for many therapeutic activities and based on the research surveys some important dry fruits and seeds are selected in this manuscript which all are having potent immune boosting activities. These dry fruits and seeds are used either in combinations or in sole in many food additives or as nutraceuticals or in any dietary supplements. Hence, in current year with the rich sources of flavonoids, polyphenolic compoundsthey are used in powder form or as a whole are used for boosting immunity and will bestow significant health benefits especially to protect the health from COVID-19 virus infection.

\section{Conflict of interest}

The authors declare that there are no conflicts of interest relevant to this article. 


\section{References}

Abdel-Rahman, M.K. (2006). Effect of pumpkin seed (Cucurbitapepo L.) diets on benign prostatic hyperplasia (BPH): Chemical and morphometric evaluation in rats. World J. Chem., 1:33-40.

Acosta-Patiño, J.L.; Jiménez-Balderas, E.; Juárez-Oropeza, M.A. and Díaz Zagoya, J.C. (2001). Hypoglycemic action of Cucurbita ficifolia on Type 2 diabetic patients with moderately high blood glucose levels. J. Ethnopharmacol., 77:99-101.

Aguilar, N.; Albanell, E.; Miñarro, B. and Capellas, M. (2016). Chestnut flour sourdough for gluten-free bread making. European Food Research and Technology, 242:1795-1802.

Al-Farsi, M.A. and Lee, C.Y. (2008). Nutritional and functional properties of dates: A review. Crit. Rev. Food. Sci. Nutr., 48(10):877-887.

Amarowicz, R.; Troszyńska, A. and Shahidi, F. (2005). Antioxidant activity of almond seed extract and its fractions. J. Food. Lipids, 12(4): 344-358.

Andayanie, W.R.; Nuriana, W. and Ermawati, N. (2019). Antiviral activity of cashew nutshell extract against cowpea mild mottle virus on soybean. J. HPT Tropika, 19(2):170-178.

Arcan, I. and Yemenicioglu, A. (2009). Antioxidant activity and phenolic content of fresh and dry nuts with or without the seed coat. Journal of Food Composition and Analysis., 22:184-188.

Arena, A.; Bisignano, C.; Stassi, G.; Mandalari, G.; Wickham, M.S. and Bisignano, G. (2010). Immunomodulatory and antiviral activity of almond skins. Immunol. Lett., 132(1-2):18-23

Bashir, T.; Mashwani, Z.R.; Zahara, K.; Haider, S. and Mudrikah, T.S. (2015). Chemistry, pharmacology and ethnomedicinal uses of Helianthus annuus (sunflower): A review. Pure Appl Biol., 4(2):226-235.

Beyhan, O.; Elmastaş, M. and Gedikl, F. (2010). Total phenolic compounds and antioxidant capacity of leaf, dry fruit and fresh fruit of feijoa (Accasellowiana, Myrtaceae). Journal of Medicinal Plants Research, 4(11):1065-1072.

Biglari, F.; Alkarkhi, A.F.M. and Easa, A.M. (2008).Antioxidant activity and phenolic content of various date palm (Phoenix dactylifera) fruits from Iran. Food Chemistry, 107(4):1636-1641.

Braga, N.; Rodrigues, F.and Oliveira, P.P.M.B. (2015). Castanea sativa byproducts: A review on added value and sustainable application. Nat Prod. Res., 29(1):1-18. https://doi.org/10.1080/14786419. 2014. 955488 .

Caliskan, O. and Polat, A.A. (2011). Phytochemicals and antioxidant properties of selected fig (Ficus carica L.) accessions from the eastern Mediterranean region of Turkey. Scientia Horticulturae, 128(4):473-478.

Câmara, C.R.S. and Schlegel, V. (2016). A review on the potential human health benefits of the black walnut: A comparison with the English walnuts and other tree nuts, International Journal of Food Properties, 19(10):2175-2189

Camero, M.; Marinaro, M.; Lovero, A.; Elia, G.; Losurdo, M.; Buonavoglia, C. and Tempesta, M. (2014). In vitro antiviral activity of Ficus carica latex against caprineherpesvirus-1. Nat. Prod. Res., 28(22):2031-2035.

Casas-Agustench, P.; Bullo, M.; Ros, E.; Basora, J. and Salas-Salvadó, J. (2011) Nureta-PREDIMED investigators. Cross-sectional association of nut intake with adiposity in a Mediterranean population. Nutr. Metab. Cardiovasc Dis., 21(7):518-525.

Chen, W.J.; Xu, ZY.; Mu, J.S.; Yang, L.; Gan, H.X. and Mu, F.(2004). Antibody response and viraemia during the course of severe acute respiratory syndrome (SARS)-associated coronavirus infection. J Med Microbiol., 53:435-438.
Coccia, E.; Siano, F.; Volpe, M.G.; Varricchio, E.; Eroldogan, O.T. and Paolucci, M. (2019). Chestnut shell extract modulates immune parameters in the rainbow trout oncorhynchus mykiss. Fishes, 4:18; doi:10.3390/ fishes4010018.

Do Prado, A.C.P.; da Silva, H.S.; da Silveira, S.M.; Barret Manique, P.L.; Werneck Vieira, C.R.; Maraschin, M.; Salvador Ferreira, S.R. and Mara Block, J. (2014). Effect of the extraction process on the phenolic compounds profle and the antioxidant and antimicrobial activity of extracts of pecan nut [Carya illinoinensis (Wangenh) C. Koch] Shell. Ind. Crops Prod., 52:552-561.

Dong, Y.; Dai, T.; Wei, Y.; Zhang, L.; Zheng, M. and Zhou, F. (2020). A systematic review of SARS-CoV-2 vaccine candidates. Sig Transduct Target Ther., 5:237. https://doi.org/10.1038/s41392-020-00352-y.

Fernández Montero,A.; Bes Rastrollo, M.; Beunza, J. J.; Barrio Lopez, M. T.; de la Fuente Arrillaga, C.; Moreno Galarraga, L. and Martinez-Gonzalez, M.A. (2013). Nut consumption and incidence of metabolic syndrome after 6 year follow up: the SUN (Seguimien to Universidad de Navarra., University of Navarra Follow up) cohort. Public Health Nutr., 16:20642072.

Gao, J.; Tian, Z. and Yang, X. (2020). Break through: Chloroquinephosphate has shown apparent efficacy in treatment of COVID-19 associated pneumonia in clinical studies. Biosci. Trends, 14(1):72-73.

Gayathiri, K.; Gopi Sudheer Kumar, J. and Kavimani, S. (2017). Evaluation of immunomodulatory activity of Salviahispanica L. seeds. Research J. Pharm. and Tech., 10(12):4255-4260.

Geo Vigila, A and Baskaran, X. (2008). Immunomodulatory effect of coconut protein on cyclophosphamide induced immune suppressed swiss albino mice. Ethnobotanical Leaflets, 12:1206-1212.

Gentile, C.; Tesoriere, L.; Butera, D.; Fazzari, M.; Monastero, M.; Allegra, M. and Livrea, M.A. (2007). Antioxidant activity of sicilian pistachio (Pistaciavera L. Var. Bronte) nut extract and its bioactive components. Journal of Agricultural and Food Chemistry, 55(3): 643-648.

Ghaseminasab, P. M.; Ahmadi, A. and Mazloomi, S,M. (2015). A review on pistachio: Its composition and benefits regarding the prevention or treatment of diseases. Journal of Occupational Health and Epidemiology, 4(1):57-69.

Giada, M.D. and Mancini-Filho, J. (2009). Antioxidant capacity of the striped sunflower (Helianthus annuus L.) seed extracts evaluated by three in vitro methods. Int. J. Food Sci. Nutr., 60(5):395-401.

Griel, A. E. and Kris-Etherton, P. M. (2006). Nuts: source of energy and macronutrients. British Journal of Nutrition, 96:S29-S35.

Hamsar, M.N.; Ismail, S.; Mordi, M.N.; Ramanathan, S. and Mansor, S.M. (2011). Antioxidant activity and the effect of different parts of Areca catechu extracts on Glutathione-S-Transferase activity in vitro. Free Radicals and Antioxidants, 1(1):28-33.

Hasan, N.S.; Amom, H.Z.;Nor, A.I.; Mokhtardin, N.; MohdEsa, N. and Azlan, A. (2010). Nutritional composition and in vivo evaluation of the antioxidant properties of various date extract (Phoenix dactylifera) from Libya. Asian Journal of Clinical Nutrition, 2(4):208-214.

Hardin-Fanning, F. (2008). The effects of a Mediterranean-style dietary pattern on cardiovascular disease risk. Nurs. Clin. North Am., 43(1): 105-115

Jassim, S.A. andNaji, M.A. (2010). In vitro evaluation of the antiviral activity of an extract of date palm (Phoenix dactylifera L.) pits on a pseudomonas phage. Evid. Based Complement Alternat. Med., 7(1):57-62.

Jeszka-Skowron, M. and Czarczynska-Goslinska, B. (2020). Chapter 21 - Raisins and the other dried fruits: Chemical profile and health benefits. The Mediterranean Diet, $2^{\text {nd }}$ Edition, pp:229-238. 
Kamal J. (2011). Quantification of alkaloids, phenols and flavonoids in sunflower (Helianthus annuus L.). Afr. J. Biotechnol., 10(16):31493151 .

Kasote, D.M.; Zanwar,A.A.; Devkar, S.T.; Hegde, M.V. and Deshmukh, K.K. (2012) Immunomodulatory activity of ether insoluble phenolic components of n-butanol fraction (EPC-BF) of flaxseed in rat. Asian Pacific journal of Tropical Biomedicine, 2(2):S623-S626.

Kaur, S.P. and Gupta, V. (2020). Covid-19 vaccine: A comprehensive status report.Virus Res., 288:198114. https://doi.org/10.1016/ J. virusres. 2020.198114

Kelebek, H.; Jourdes, M.; Selli, S. and Teissedre, P.L. (2013). Comparative evaluation of the phenolic content and antioxidant capacity of sun-dried raisins. J. Sci. Food Agric., 93(12):2963-2972.

Khan, A.A; Khan, S.; Khan, U. and Das, K. (2020). The COVID-19 pandemicA Scoping review. Ann. Phytomed., 9(1):18-26.

Kornsteiner, K.M.; Wagner, K.H. and Elmadfa, I. (2013). Phytosterol conten and fatty acid pattern of ten different nut types. Int. J. Vitam. Nutr. Res., 83(5):263-70.

Kyriakidis, N.C.; López-Cortés, A.; González, E.V.; Grimaldos, A.B. and Prado, E.O. (2021). SARS-CoV-2 vaccines strategies: A comprehensive review of phase 3 candidates. npj Vaccines, 6:28. https://doi.org/10.1038/ s41541-021-00292-w.

Li,W.; Shi, Z.; Yu, M.; Ren,W.; Smith, C.; Epstein, J.H.; Wang, H.;Crameri, G.; Hu, Z; Zhang, H.; Zhang, J.; McEachern, J.; Field, H.; Daszak, P.; Eaton, B.T.; Zhang, S. and Wang, L.F. (2005). Bats are natural reservoirs of SARS-like coronaviruses. Science, 310:676-679.

Li, S.; Chen, G.; Zhang, C.; Wu, M.; Wu, S. and Liu, Q. (2014). Research progress of natural antioxidants in foods for the treatment of diseases. Food Sci. Hum. Wellness., 3(3-4):110-116.

Li, J.N.; Henning, S.M.; Thames, G; Bari, O.; Tran, P.T.; Tseng, C.H.; Heber, D.; Kim, J. and Li, Z. (2021). Almond consumption increased UVB resistance in healthy Asian women. J. Cosmet Dermatol., 001:1-6. http://doi.org/ 10.1111 /jocd.13946.

Limmongkon, A.; Janhom, P.; Amthong, A.; Kawpanuk, M.; Nopprang, P.; Poohadsuan, J.;Somboon, T.; Saijeen, S.; Surangkul, D.;Srikummool, M. and Boonsong, T. (2017). Antioxidant activity, total phenolic, and resveratrol content in five cultivars of peanut sprouts. 7(4):332338

Lu, R.; Zhao, X.; Li, J.; Niu, P.; Yang, B.; Wu, H.; Wang, W.; Song, H.; Huang, B.; Zhu, N.; Bi, Y.; Ma, X.; Zhan, F.; Wang, L.; Hu, T.; Zhou, H.; Hu, Z.; Zhou, W.; Zhao, L.; Chen, J.; Meng, Y.; Wang, J.; Lin, Y.; Yuan, J.; Xie, Z.; Ma, J.; Liu, W.J.; Wang, D.; Xu, W.; Holmes, E.C.; Gao, G.F.; Wu, G.; Chen, W.; Shi, W. and Tan, W. (2020). Genomic characterisation and epidemiology of 2019 novel coronavirus: implications for virus origins and receptor binding. Lancet, 395:565-574.

Lupini, C.; Cecchinato, M.; Scagliarini, A.; Graziani, R. and Catelli, E. (2009). In vitro antiviral activity of chestnut and quebracho woods extracts against avian reovirus and metapneumovirus. Res. Vet. Sci., 87(3): 482-487.

Madaru, M.A.; Sanguinetti, A.M.; Caro, A.D.; Fadda, C. and Piga, A. (2010) Contribution of melanoidins to the antioxidant activity of prunes. J. Food Qual, 33:155-170.

Makau, J.N.; Watanabe, K.; Mohammed, M.M.D and Nishida, N. (2018). Antiviral activity of Peanut (Arachishypogaea L.) skin extract against human influenza viruses. Journal of Medicinal Food, 21(8):777-784.

Mandalari, G.; Tomaino, A.; Rich, G.T.; Lo Curto, R.B.; Bisignano, C.; Saija, A.; Parker, M.L.; Waldron, K.W. and Wickham, M.S.J. (2010). Polyphenol and nutrient release from skin of almonds during simulated human digestion. Food Chem., 122:1083-1088.
Mao, R.; Wu, L.; Zhu, N.; Liu, X.; Hao, Y; Liu, R.; Du, Q. and Li, Y. (2020). Immunomodulatory effects of walnut (Juglansregia L.) oligopeptides on innate and adaptive immune responses in mice. Journal of Functional Foods, 73:104068.

Martinez-Cruz, O. and Paredes-Lopez, O. (2014). Phytochemical profile and nutracetical potential of Chia seeds (Salvia hispanica L.) by ultra high performance liquid chromatography. J. Chromatogr. A. 1346: $43-48$.

Mattison, C.P.; Aryana, K.J.; Clermont, K.; Prestenburg, E.; Lloyd, S.W.; Grimm, C.C. and Wasserman, R.L. (2020). Microbiological, Physicochemical, and Immunological Analysis of a Commercial Cashew Nut-Based Yogurt. Int. J. Mol. Sci., 21:8267; doi:10.3390/ijms21218267.

Minaiyan, M.; Ghannadi,A.; Asadi, M.; Etemad, M. and Mahzouni, P. (2014). Antiinflammatory effect of Prunusarmeniaca L. (Apricot) extracts ameliorates TNBS-induced ulcerative colitis in rats. Res. Pharm. Sci., 4:225-231.

Musarra-Pizzo, M.; Ginestra, G.; Smeriglio, A.; Pennisi, R.; Sciortino, M.T. and Mandalari, G. (2019). The antimicrobial and antiviral activity of polyphenols from almond (Prunusdulcis L.) skin. Nutrients, 11: 2355; doi:10.3390/nu11102355.

Musarra-Pizzo, M.; Pennisi, R.; Ben-Amor, I.; Smeriglio, A.; Mandalari, G. and Sciortino, M.T. (2020). In vitro Anti-HSV-1 activity of polyphenol-rich extracts and pure polyphenol compounds derived from pistachios kernels (Pistaciavera L.). Plants, 9:267, doi:10.3390/plants 9020267.

Nikolaeva-Glomba, L.; Mukovaa, L.; Nikolovaa, N.; Badjakovb, I.; Dinchevab, I.; Kondakovab, V.; Doumanovaa, L. and Galabov, A.S. (2014). In vitro antiviral activity of a series of wild berry fruit extracts against representatives of picorna, Orthomyxo and Paramyxoviridae. Natural Product Communications, 9(1):51-54.

Nishide, M.; Ikeda, K.; Mimura, H.; Yoshida, M.; Mitani, T. and Hajime K.A. (2019) Antiviral and virucidal activities against herpes simplex viruses of umesuphenolics extracted from Japanese apricot. Microbiology and Immunology, 63:359-366.

Oh, C.S.; Price, J.; Brindley, M.A.; Widrlechner, M.P.; Qu, L.; McCoy, J.A.; Murphy, P.; Hauck, C. and Maury, W. (2011). Inhibition of HIV-1 infection by aqueous extracts of Prunella vulgaris L. Virology Journal, 8:188 doi:10.1186/ $1743-422 \mathrm{X}-8-188$.

Oliveira, M.G.M.; Bueno, O.F.A.;Pomarico, A.C. and Gugliano, E.B. (1997). Strategies used by hippocampal and caudate-putamen-lesioned rats in a learning task. Neurobiol Learn Mem, 68:32-41.

Oliveira, I.; Meyer, A.; Afonso, S.; Ribeiro, C. and Gonçalves, B. (2018). Morphological, mechanical and antioxidant properties of Portuguese almond cultivars. Journal of Food Science and Technology, 55(2):467-478.

Oliver-Chen, C.Y. and Blumberg, J.B. (2008). Phytochemical composition of nuts. Asia Pac. J. Clin. Nutr., 17(1):329-332.

Orhan, D.D.; Orhan, N.; Ozcelik, B. and Ergun, F. (2009). Biological activities of Vitisvinifera L. leaves. Turk. J. Biol., 33:341-348.

Ozkutlu, F.; Dogru, Y.Z; Ozenc, N.; Yazýcý, G.; Turan, M. and Akcay, F. (2011). The importance of Turkish hazelnut trace and heavy metal contents for human nutrition. J. Soil Sci., Environ. Manag., 2:25-33.

Pająk, P.; Socha, R.; Gałkowska, D.; Rożnowski, J. and Fortuna, T. (2014). Phenolic profile and antioxidant activity in selected seeds and sprouts. Food Chem., 143:300-306.

Pal, P.; Singh, S.B. and Singh, A. (2018). Determination of physicochemical properties, antioxidant constituents by high-performance thin-layer chromatography fingerprinting, and antioxidant activity of Cucurbita maxima seeds. Asian J. Pharm. Clin. Res., 11(3): 280-283. 
Pasko, P.; Barton, H.; Zagrodzki, P.; Gorinstein, S.; Folta, M. and Zachwieja, Z. (2009). Anhocyanins, total polyphenols and antioxidant activity in amaranth and quinoa seeds and sprouts during their growth. Food Chem., 115(3):994-998.

Patel, S.K.; Pathak, M.; Tiwari, R.; Yatoo, M.I.; Malik, Y.S.; Sah, R.; Rabaan,A.A.; Khan, S.; Dhama, K.; Bonilla-Aldana, D.K. and Rodriguez-Morales, A.J. (2020). A vaccine is not too far for COVID-19. J. Infect. Dev. Ctries, 14(5): $450-453$.

Porras-Loaiza, P.; Jiménez-Munguía, M.T.; Sosa-Morales, M.E.; Palou, E. and LopezMalo, A. (2014). Physical properties, chemical characterization and fatty acid composition of Mexican chia (Salvia hispanica $\mathbf{L}$.) seeds. International Journal of Food Science and Technology, 49:571577

Prakruthi, A.; Sunil, L.; Prasanth Kumar, P.K. and Gopala Krishna, A.G. (2015) Physicochemical characteristics and stability aspects of coconut water and kernel at different stages of maturity. Journal of Food Science and Technology, 52(8):5196-5203.

Prakruthi, A.; Sunil, L.; Gopala Krishna, A. G. and Suresh Kumar, G. (2016) Phytochemicals and antioxidant activity of testa extracts of commercial wet and dry coconuts and cakes. Int. Res. J. Pharm., 7 (9):9-13.

Pycia, K.; Kapusta, I. and Jaworska, G. (2020).Changes in Antioxidant Activity, Profile, and Content of Polyphenols and Tocopherols in Common Hazel Seed (Corylus avellana L.) Depending on Variety and Harvest Date. Molecules, 25(1):43, https://doi.org/10.3390/molecules 25010043.

Ramadan, A.; Kamel, G.; Shokry, A.A. and El-Shiekh, R.A. (2020). A potent antiageing and immunomodulatory activity of apricot seed standardized extract and its major compound; Amygdalin. Trop. J. Nat. Prod. Res., 4(10):728-733.

Rasne, A.; Sonwane, V.; Somani, R. and Kumthekar, P. (2018). Evaluation of immunomodulatory activity of protocatechuic acid. J. Res. Notes, 1(1):1007.

Richardson, D.P.; Astrup, A.; Cocaul, A. and Ellis, P. (2009). The nutritional and health benefits of almonds: A healthy food choice. food science and technology bulletin: Functional Foods, 6(4):41-50.

Rivas, A.; Romero, A.; Mariscal Arcas, M.; Monteagudo, C.; Feriche, B.; Lorenzo M. L. and Olea, F. (2013). Mediterranean diet and bone mineral density in two age groups of women. Int. J. Food Sci. Nutr., 64:155-161.

Sachdeva, M.K. and Katyal, T. (2011). Abatement of detrimental effects of photo aging by Prunusamygdalus skin extract. International Journal of Current Pharmaceutical Research, 1(3):57-59.

Sari, L. M.; Hakim, R. F.; Mubarak, Z. and Andriyanto, A. (2020). Analysis of phenolic compounds and immunomodulatory activity of areca nut extract from Aceh, Indonesia, against Staphylococcus aureus infection in Sprague-Dawley rats. Veterinary World, 13(1):134-140.

Segura, R.; Javierre, C.; Lizarraga, M.A. and Ros, E. (2006). Other relevant components of nuts, phytosterols, folate, and minerals. British Journal of Nutrition, 96:S36-S44.

Sharma, S.; Satpathy, G. and Gupta, R.K. (2014). Nutritional, phytochemical, antioxidant and antimicrobial activity of Prunusarmenicus. J. Pharmacogn. Phytochem, 3:23-28.

Silva, V.; Falco, V.; Dias, M.I.; Barros, L.; Silva, A.; Capita, R.; Calleja, C.A.; Amaral, J.S.; Igrejas, G.; Ferreira, I.C.F.R. and Poeta, P. (2020). Evaluation of the phenolic profile of Castanea sativa Mill. By products and their antioxidant and antimicrobial activity against multiresistant bacteria. Antioxidants, 9:87; doi:10.3390/antiox9010087.
Slavova-Kazakova, A.; Karamac, M.; Kancheva, V. and Amarowicz. R. (2016). Antioxidant activity of flaxseed extracts in lipid systems. Molecules, 21(1): 17 .

Soares, D.J.; Do-Carmo, J.S.; Lima, J.D.S.S.; Maia, G.A.; De-Sousa, P.H. M and DeFigueiredo, R.W. (2013). Polyphenols and antioxidant activity of cashew nuts from conventional and organic cultivation in different stages of processing.Boletim do Centro de Pesquisa de Processamen to de Alimentos, 31(1):173-181.

Song, C.W.; Wang, S.M.; Zhou, L.L.; Hou, F.F.; Wang, K.J.; Han, Q.B.; Li, N. and Cheng, Y.X. (2011). Isolation and identification of compounds responsible for antioxidant capacity of Euryale ferox seeds. J. Agric. Food Chem., 59(4):1199-1204.

Soussi, A.; Gargouri, M. and Feki, A.E. (2018). Potential immunomodulatory and antioxidant effects of walnut Juglansregia vegetable oil against lead-mediated hepatic damage and their interaction with lipase activity in rats. Environ Toxicol, 33(12):1261-1271.

Stacewicz Sapuntzakis, M.; Bowen, P.E.; Hussain, E.A.; Damayanti Wood, B.I. and Farnsworth, N.R. (2001). Chemical composition and potential health effects of prunes: a functional food? Crit. Rev. Food Sci. Nutr., 41:251-86.

Taghizadeh, F.; Davarynejad, G.; Asili, J.; Nemati, H. and Karimi, G. (2018). Assessment of phenolic profile and antioxidant power of five pistachio (Pistaciavera L.) cultivars collected from four geographical regions of Iran. Avicenna J. Phytomed., 8(1):33-42.

Tang, Z.X.; Shi, L.E. and Aleid, S.M. (2013). Date fruit: chemical composition, nutritional and medicinal values, products. J. Sci. Food. Agric, 93(10): 2351-2361.

Tian, J.;Yuan, X.; Xiao, J.; Zhong, Q.; Yang, C.; Liu, B.; Cai, Y.; Lu, Z.; Wang, J.; Wang, Y.; Liu, S.; Cheng, B.; Wang, J.; Zhang, M.; Wang, L.; Niu, S.; Yao, Z.; Deng, X.; Zhou, F.; Wei, W.; Li, Q.; Chen, X.; Chen, W.; Yang, Q.; Wu, S.; Fan, J.; Shu, B.; Hu, Z.; Wang, S.; Yang, X.P.; Liu, W.; Miao, X. and Wang, Z. (2020). Clinical characteristics and risk factors associated with COVID-19 disease severity in patients with cancer in Wuhan, China: A multicentre, retrospective, cohort study. Lancet Oncol, 21:893903.

Tong, H.; Song, X.; Sun, X.; Sun, G. and Du, F. (2011). Immunomodulatory and antitumor activities of grape seed proanthocyanidins. J. Agric. Food Chem., 59(21):11543-11547.

Towbin, H.; Stachelin, T. and Gordon, J.(1979). Electrophoretic transfer of proteins from polyacrylamide gels to nitrocellulose sheets: procedure and some applications. Proc. Natl. Acad. Sci., 76:43504354.

Trox, J.;Vadivel, V.; Vetter, W.; Stuetz, W.; Scherbaum,V.; Gola, U.; Nohr, D. and Biesalski, H.K. (2010). Bioactive compounds in cashew nut (Anacardium occidentale L.) kernels: Effect of different shelling methods. J. Agric. Food Chem., 58:5341-5346.

Van Doremalen, N.;Bushmaker, T.; Morris, D.H.; Holbrook, M.G.; Gamble, A.; Williamson, B.N.; Tamin, A.; Harcourt, J.L.; Thornburg, N.J.; Gerber, S.I.; Lloyd-Smith, J.O.; de-Wit, E. and Munster, V. (2020). Aerosol and surface stability of SARS-CoV-2 as compared with SARS-CoV-1. N. Engl. J. Med., 382:1564-1567.

Vardhini, S.R.D. (2014). Exploring the antiviral activity of juglone by computational method J. Recept. Signal. Transduct. Res., 34(6):456-457.

Vinson, J.A. (1999). The functional food properties of Figs. Cereal Foods world, 44(2):82-87.

Wani, S.M.; Jan, N.; Wani, T.A.; Ahmad, M.; Masoodi, M.A. and Gani, A. (2017). Optimization of antioxidant activity and total polyphenols of dried apricot fruit extracts (Prunusar meniaca L.) using response surface methodology. Journal of the Saudi Society of Agricultural Sciences, 16(2):119-126 
Weijun,C.;Minghua,Y.;Ling,Y.;Ding, B.; He, B.; Wang, Y.; Liu, X.; Liu, C.; Zhu, H.; You, B.;Huang, S.; Zhang, J.; Mu, F.; Xiang, Z; Feng, X.; Wen, J.; Fang, J.; Yu, J.; Yang, H. and Wang, J. (2005). SARS-associated coronavirus transmitted from human to pig. Emerg. Infect. Dis. J., 11:446-448.

Williamson, G. and Carughi, A. (2010). Polyphenol content and health benefits of raisins. Nutr. Res., 30(8):511-519.

Willis, L.M.; Shukitt-Hale, B. and Joseph, J.A. (2009). Modulation of cognition and behavior in aged animals: role for antioxidant- and essential fatty acid-rich plant foods. Am. J. Clin. Nutr., 89:S1602-S1606.

World Health Organization. (2020). WHO Director General's opening remarks at the media briefing on COVID-19-11 March 2020. Available from: https://www.who.int/dg/speeches/detail/who-director-generalsopening-remarks-at-the-media-briefing-on-covid-19-11-march2020 .
Wu, Z. and McGoogan, J.M. (2020). Characteristics of and important lessons from the coronavirus disease 2019 (COVID-19) outbreak in China: summary of a report of 72314 cases from the Chinese center for disease control and prevention. Jama, 323(1):1239-1242.

Xu, J.; Jia, W.; Wang, P.; Zhang, S.; Shi, X.; Wang, X. and Zhang, L. (2019). Antibodies and vaccines against Middle East respiratory syndrome coronavirus. Emerg. Microbes. Infect., 8:841-856.

Yang, J.; Liu, R. and Halim, L. (2009). Antioxidant and antiproliferative activities of common edible nut seeds. Food Science and Technology, 42: $1-8$.

Zhao, J.; Gong, L.; Wu, L.; She, S.; Liao, Y.; Zheng, H.; Zhao, Z.; Liu, G and Yan, S. (2020). Immunomodulatory effects of fermented fig (Ficus carica L.) fruit extracts on cyclophosphamide-treated mice. Journal of Functional Foods, 75:104219.

Sravani Singirikonda, Kuntal Das, M. Saifulla Khan, R. Tejashwini and A. Jothi (2021). Edible dry fruits and 